Int. J. Dev. Biol. 53: 469-482 (2009)

doi: $10.1387 / \mathrm{ijdb} .082793 \mathrm{jr}$

\title{
Eye-specific expression of an ancestral jellyfish PaxB gene interferes with Pax6 function despite its conserved Pax6/Pax2 characteristics
}

\author{
JANA RUZICKOVA ${ }^{1}$, JORAM PIATIGORSKY ${ }^{2}$ and ZBYNEK KOZMIK*,1 \\ ${ }^{1}$ Institute of Molecular Genetics, Academy of Sciences of the Czech Republic, Prague, Czech Republic and \\ ${ }^{2}$ National Eye Institute, National Institutes of Health, Bethesda, Maryland, USA
}

\begin{abstract}
Pax transcription factors are evolutionarily conserved regulators of eye development and can be distinguished on the basis of three functional domains: two DNA-binding domains (the paired domain and the paired-type homeodomain), and the octapeptide motif. PaxB of the eyed cubozoan jellyfish, Tripedalia cystophora, is characterized by a Pax2-like paired domain and octapeptide, and a Pax6-like homeodomain. In mice, functionally distinct Pax6 and Pax2 proteins have unique as well as redundant roles in eye morphogenesis. Here, we show that expression of the jellyfish PaxB gene in mouse embryonic eye tissues impairs normal development of lens and retina. Our data show that PaxB misexpression leads to a downregulation of endogenous Pax6 protein in the prospective lens and in subsets of cells within the inner nuclear layer of transgenic retina. In addition to Pax6 downregulation, the expression of PaxB leads to an almost complete loss of amacrine cells in the adult transgenic retina, a phenotype that differs from a loss-offunction of the Pax6 gene. The present data suggest that PaxB, due to its Pax2-like paired domain and Pax-6 like homeodomain, disturbs the transcriptional network regulated by Pax6 in the developing lens and retina. Taken together, our data suggest that molecular properties of individual mouse Pax2 and Pax6 proteins are essential determinants of mouse eye development and cannot be substituted for by jellyfish PaxB which possesses elements of vertebrate Pax2 and Pax6.
\end{abstract}

KEY WORDS: Pax, eye, lens, retina

\section{Introduction}

Pax genes encode transcription factors critical for metazoan development. Members of the Pax protein family can be classified based on the presence and characterictic features of their three evolutionarily conserved domains: a paired domain, a paired-type homeodomain and an octapeptide. The paired domain and the paired-type homeodomain encode two independent DNA-binding domains, while the octapeptide plays an important role in proteinprotein interactions. Pax proteins interact with similar DNA sequences although differences in specificity exist. In particular, three amino acids (at positions 42,44 , and 47) within the Nterminal half of paired domain are responsible for the difference in the DNA-binding specificities between Pax6 and Pax2/5/8 subfamilies (Czerny and Busslinger, 1995). The amino acids IQN at these positions specify Pax6, whereas amino acids QRH determine Pax2/5/8 specificity (Czerny and Busslinger, 1995). $\mathrm{Pax} 2$ of the Pax2/5/8 subfamily has a DNA binding paired domain, and an octapeptide, but only a truncated homeodomain, and has been implicated in eye development both in mice and Drosophila. The Drosophila Pax2 orthologue has a key role in the development of ommatidial cone and and pigment cells (Fu and Noll, 1997). In mice, Pax2 deficiency results in eye, kidney and inner ear defects (Favor et al., 1996; Torres et al., 1996; Gehring and Ikeo, 1999). Pax6 is an evolutionarily highly conserved transcription factor that has been considered as a key regulator of the eye

Abbreviations used in this paper: $\mathrm{EE}$, ectoderm enhancer; HD, homeodomain; $\mathrm{PD}$, paired domain; RGC, retinal ganglion cell; RPC, retinal progenitor cell; RPE, retinal pigmented epithelium.

\footnotetext{
*Address correspondence to: Dr. Zbynek Kozmik. Institute of Molecular Genetics, Videnska 1083, 142 20 Prague 4, Czech Republic.

Fax: +420-24106-2110. e-mail: kozmik@img.cas.cz
}

Supplementary Material (four additional figures) for this paper is available at: http://dx.doi.org/10.1387/ijdb.082793jr

Accepted: 15 January 2009. Published online: 27 February 2009.

ISSN: Online 1696-3547, Print 0214-6282

(C) 2009 UBC Press

Printed in Spain 
A Pax6 paired domain homeodomain

$\operatorname{Pax} 2 / 5 / 8$

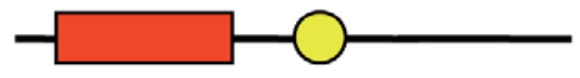

PaxB

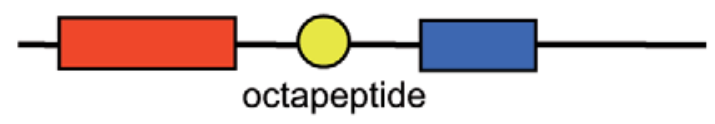

B
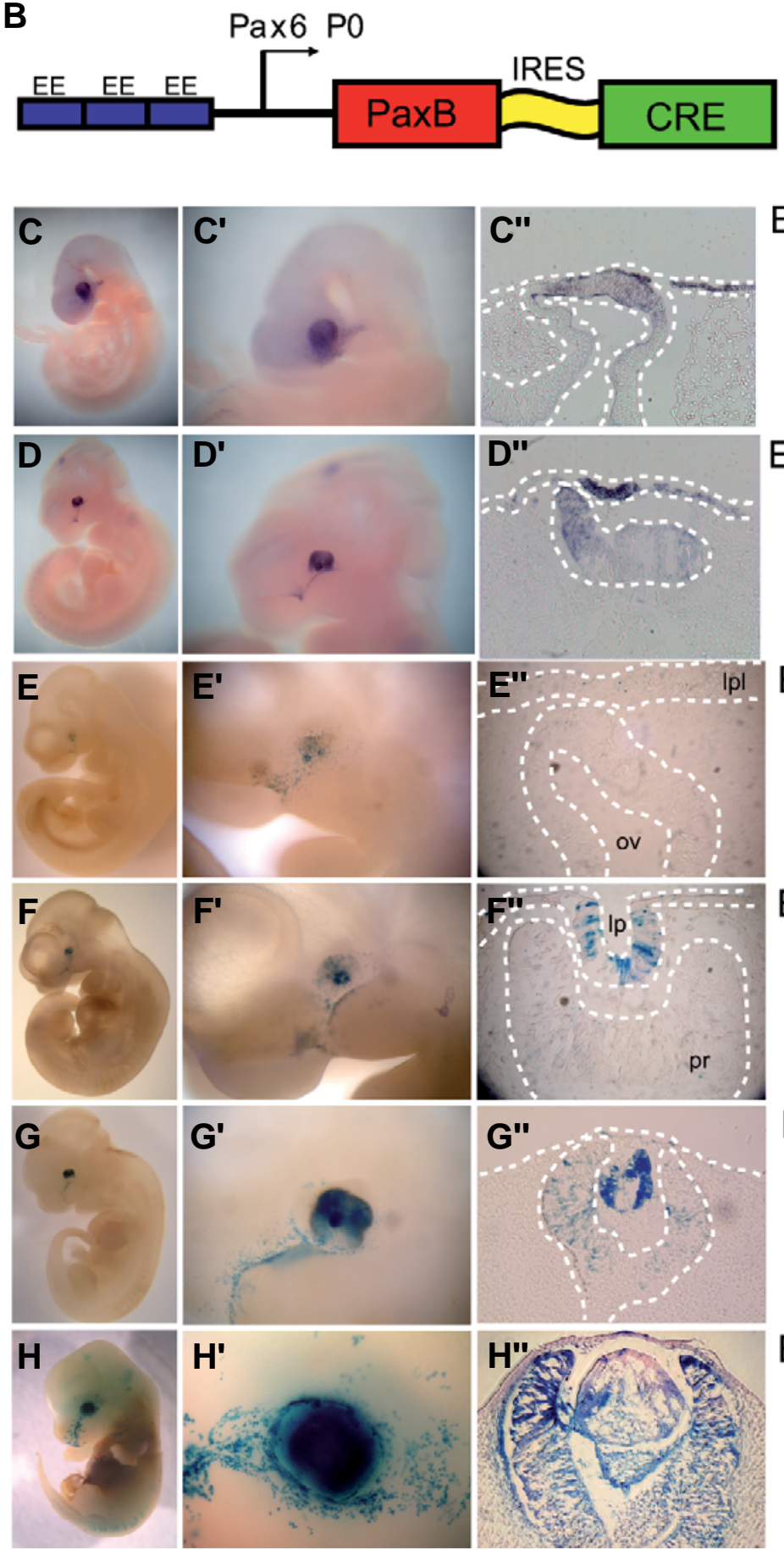
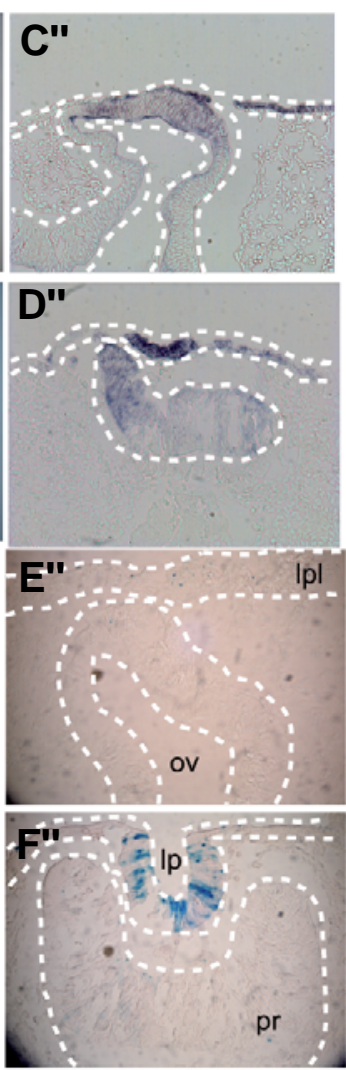

E9.5

E10.5

E9.5
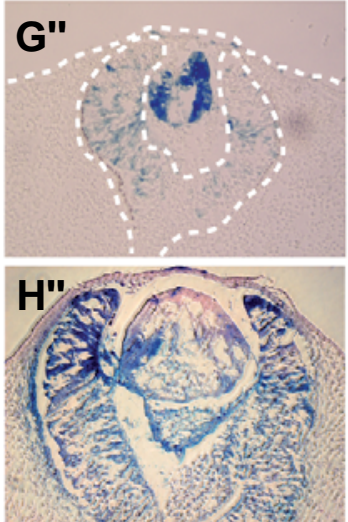

development among metazoans (Favor et al., 1996; Torres et al., 1996; Gehring and Ikeo, 1999; Gehring, 2002; Gehring, 2005; Kozmik, 2005). Pax6mutations are associated with aniridia in humans and the Small eye (Sey) phenotype in mice (Hanson and van Heyningen, 1995). Drosophila possess two Pax6 homologs, eyeless (ey) and twin of eyeless (toy), both of which are able to induce ectopic eyes (Quiring et al., 1994; Halder et al., 1995; Czerny et al., 1999). Pax6 directly activates rhodopsin genes in Drosophila (Sheng et al., 1997; Papatsenko et al., 2001) and lens crystallins of vertebrates (Cvekl and Piatigorsky, 1996; Duncan et al., 2004). Pax6 contains, in addition to the paired domain, a second DNA-binding domain, the homeodomain (HD) but it lacks the octapeptide, which is responsible for repression abilities of Pax2/ $5 / 8$ proteins mediated through interaction with Groucho co-repressors (Eberhard et al., 2000; Kozmik et al., 2003).

The Pax6 gene encodes three isoforms of Pax6 protein, and these may play different roles in eye development. The so-called canonical Pax6 protein contains the paired domain (PD) and a homeodomain (HD). Alternative RNA splicing of the Pax6 primary transcript in mice and humans leads to a second Pax6 isoform, Pax6(5a), where a peptide encoded in an additional exon is inserted within the paired domain (Epstein et al., 1994). Both isoforms mentioned above are encoded by transcripts that initiate from $\mathrm{P}_{1}$ - and $\mathrm{P}_{0}$ - Pax6 promoters (Kammandel et al., 1999; Xu et al., 1999). Finally, an isoform of Pax6 that lacks the paired domain and is encoded by the transcript starting from the $\mathrm{P}_{\text {alpha }}$ promoter has also been described (Kammandel et al., 1999; Kleinjan et al., 2004; Kim and Lauderdale, 2006).

Paired-less Pax6 is likely involved in the cell fate

Fig. 1. Construction and expression of the Pax $B$ transgene. Structure of Pax6, Pax2 and PaxB proteins; PaxB has a Pax2-like paired domain (red rectangle), a conserved octapeptide motif that is also present in Pax2 (yellow circle), and a Pax6-like

E10.5 homeodomain (b/ue rectangle) (A). Schematic diagram of the PaxB transgene Three copies of the lens-specific ectoderm enhancer (EE) derived from the Pax6 gene were cloned upstream of the Pax6 P0 minimal promoter (LR-module; Kreslova et al., 2007) to drive the expression of PaxB and Cre cDNAs connected via internal ribosomal entry site (IRES) (B). The onset of PaxB expression analyzed by whole mount RNA in situ

E11.5 hybridization at E9.5 (C,C',C") and E10.5 (D,D','") embryos. PaxB mRNA was observed in the presumptive lens ectoderm and neuroectoderm (C",D") as early at E9.5. Cre recombinase activity in PaxB transgenic mice (detected using ROSA26R reporter mice) was delayed compared to PaxB mRNA expression (E-H"). A mosaic expression of LacZ staining was detected at E9.5 (E,E',E'). At E10.5 there was strong staining for PaxB mRNA in the presumptive lens (F, F', $\left.\mathbf{F}^{\prime \prime}\right)$, and at E13.5 high

E13.5 expression levels of Cre were observed in the distal retina $(\mathbf{H}, \mathbf{H}, \mathbf{H} ")$. Please note that the lacZ-positive material in the forming vitreous cavity in ( $\left.H^{\prime \prime}\right)$ represents a histology artifact. Abbreviations used in this, and in subsequent figures are as follows: el, eye lids; I, lens; Ip, lens pit; Ipl, lens placode; ov, optic vesicle; pce, presumptive corneal epithelium; pr, presumptive retina. 
decision leading to the generation of amacrine cells since its immunoreactivity can be detected in the subset of GABAergic amacrine cells (Lakowski et al., 2007). Overexpression of Pax6 $\mathrm{PD}$ in the distal retina results in a microphthalmic phenotype (Kim and Lauderdale, 2006). In general, Pax6 function depends on a proper expression level; any change in the dosage of Pax6 protein disrupts eye development (Schedl et al., 1996; Collinson et al., 2000; van Raamsdonk and Tilghman, 2000; Davis-Silberman et al., 2005; Kim and Lauderdale, 2006). The expression of Pax 6 in lens is driven by an ectoderm enhancer (EE) (Williams et al., 1998; Kammandel et al., 1999). Targeted deletion of EE is accompanied by distinctive defects at every stage of lens development (Dimanlig et al., 2001). In addition the exact dosage of Pax6 protein is required for lens placode formation (Collinson et al., 2000; van Raamsdonk and Tilghman, 2000; Davis-Silberman et al., 2005). Moreover Pax6activity in the lens primordium is necessary for correct placement of the retina in the eye (Ashery-Padan et al., 2000). Pax6 expression is maintained throughout retina development, from early optic vesicle formation to specification of neuroretina and differentiation and timing of distinct retinal cell types. Pax 6 protein is abundant in proliferative zones of the neuroretina and subsequently in three types of retinal neurons: RGC, amacrine and horizontal cells. Null mutations in Pax6 arrest optic vesicle formation early in eye development (Hogan et al., 1986; Grindley et al., 1995). Nevertheless retinal progenitor cells (RPCs) differentiate in the optic vesicle of Pax6 mutant mice, earlier than in wild-type, although exhibiting reduced proliferation (Philips et al., 2005). Pax6 is known to control the proliferation rate of neuroepithelial progenitors (Duparc et al., 2007) and retinal stem cells in the mouse optic vesicle (Xu et al., 2007). Conditional inactivation of Pax 6 in RPCs of the distal retina prior to initiating retinogenesis resulted in reduced RPCs

Fig. 2. Phenotypes of PaxBtransgenic mice. Cryosections at the indicated embryonic stages from the wild-type and PaxB transgenic mice were stained either with hematoxylin and eosin (A, B, C, $\mathbf{D}, \mathbf{E}, \mathbf{F}, \mathbf{J}, \mathbf{K}, \mathbf{L}, \mathbf{P}, \mathbf{Q}, \mathbf{R})$ or lac- $\mathbf{Z}(\mathbf{G}, \mathbf{H}, \mathbf{I}, \mathbf{M}, \mathbf{N}, \mathbf{O})$ We sorted $\mathrm{PaxB}$ transgenic mice with weak and strong phenotypes based on the observed intensity of transgene expression $(\mathbf{H}, \mathbf{I}, \mathbf{N}, \mathbf{O})$ and lens defects. At E10.5 the transgenic lens pit $(\mathbf{B}, \mathbf{C})$ appeared similar to that in the wild-type mice (A). At E11.5 and thereafter formation of the lens vesicle was delayed in $\mathrm{PaxB}$ mice, resulting in a smaller lens $(\mathbf{F}, \mathbf{I}, \mathbf{L}, \mathbf{O}, \mathbf{R})$. At E13.5 mosaic lacZ staining was detected both in the lens and retina (N) of the transgenic mice with weak phenotypes; by contrast, the transgenic mice with strong phenotypes stained mainly in the lens vesicle (I) at E11.5, however, at E13.5-strong staining was observed also in the distal retina and surface ectoderm (0). A severe micropthalmic phenotype was revealed in the transgenic embryos (left in $\mathbf{S} ; \mathbf{T}, \mathbf{V}, \mathbf{X}$ ) compared to the wild-type embryos (right in $\mathbf{S} ; \mathbf{U}, \mathbf{W}, \mathbf{Y}$ ) at E17.5 (S,T,U) and in adults $(\mathbf{V}, \mathbf{W}, \mathbf{X}, \mathbf{Y})$. Note the open eye lids in the transgenic mice (marked with black arrow in T). proliferation and exclusive differentiation of amacrine neurons (Marquardt et al., 2001). By contrast, differentiating neurons were identified in the absence of amacrine cells in Pax6 mutant optic vesicles of Sey ${ }^{1 \mathrm{Neu}}$ mice (Philips et al., 2005).

It is apparent that in mice, Pax6 and Pax2 play distinct as well

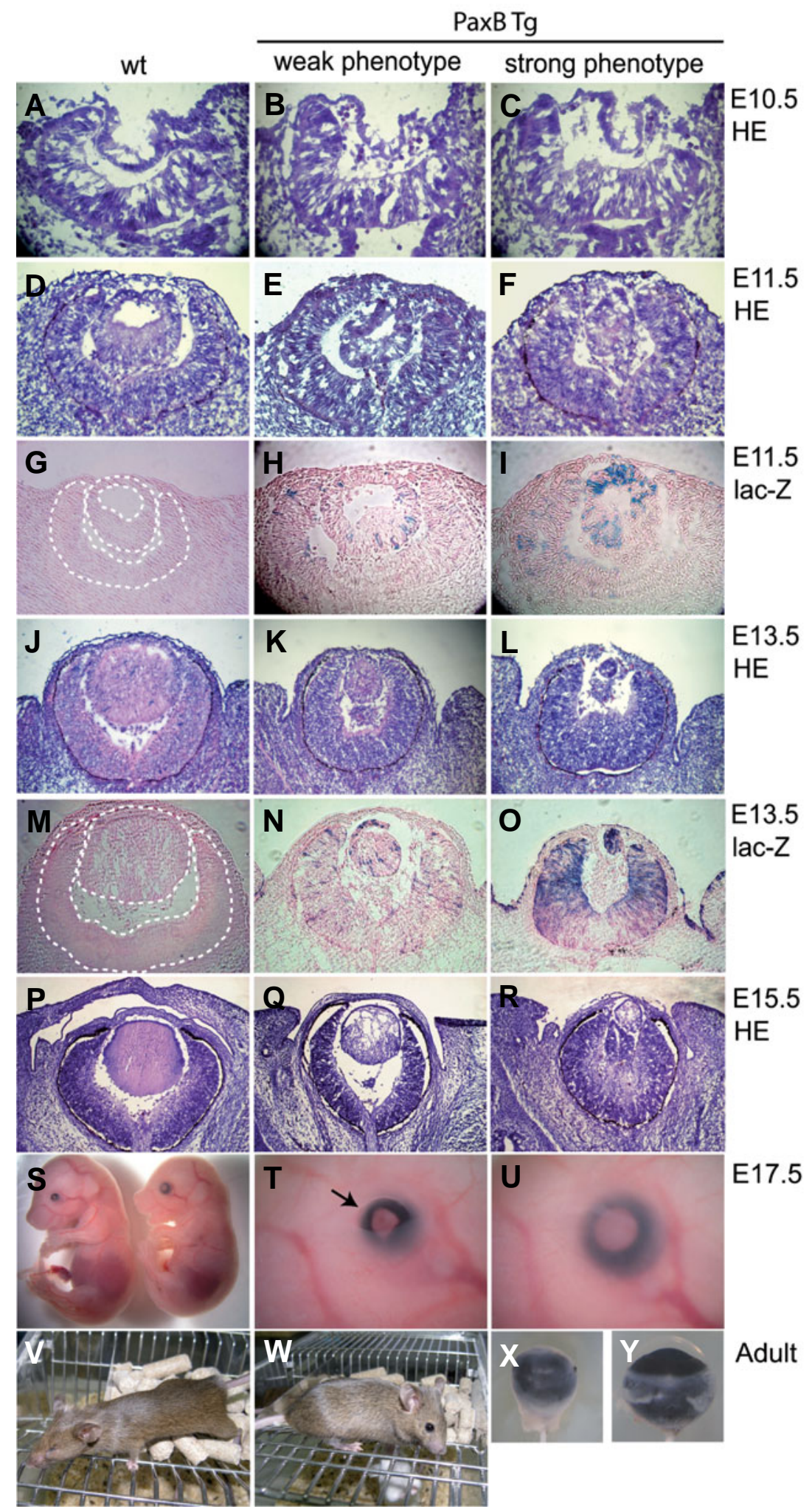


as redundant roles during the eye development. Pax6 is expressed in the developing mouse eye in the prospective lens, retina and pigmented epithelium and Pax6 mutations cause several eye defects. Pax2 is initially co-expressed with Pax6 within the optic vesicle, but soon after invagination of the optic cup Pax2 expression becomes restricted to the optic stalk (Nornes et al., 1990; Torres et al., 1996). In contrast to Pax6, the Pax2 protein can not be found in lens at any time during eye development. However, redundant activities of Pax2 and Pax6 specify the optic cup/optic stalk boundary (Schwarz et al., 2000) and determinate the retinal pigmented epithelium (RPE) in the mouse eye (Baumer et al., 2003). There are Pax2- and Pax6binding sites on the retina enhancer of the Pax6gene and on the Pax2 upstream control region (Schwarz et al., 2000). The Pax2 protein cooperates with Vax transcription factors to repress Pax6 expression in the ventral region of the optic vesicle and the optic stalk (Mui et al., 2005).

Cnidaria are the most basal organisms which possess camera-type eyes and Pax genes (Kozmik et al., 2003). PaxB protein of cubosoan jellyfish, Tripedalia cystophora, has a Pax2-like paired domain, and a Pax6-like homeodomain, and an octapeptide. Three amino acids $(Q, R, H)$ responsible for DNA binding specificities of the PaxB paired domain are identical to those in the paired domain of $\mathrm{Pax} 2 / 5 / 8$, however the Pax6-like homeodomain of jellyfish PaxB allows it to activate the Drosophila rhodopsin promoter. Like Pax6, PaxB can induce small ectopic eyes in Drosophila (Kozmik et al., 2003). PaxB also has Pax2 traits. It has the activation and inhibitory domains typical of the Pax2/5/8 subfamily of proteins and it rescues the Drosophila Pax2 eye mutant (Kozmik et al., 2003). Taken together PaxB of jellyfish Tripedalia cystophora can carry on functions of both Pax6 and Pax2 in higher metazoans (Kozmik et al., 2003). Here we investigate further the functional properties of jellyfish PaxB by expressing it in the developing lens and retina of transgenic mice.

\section{Results}

\section{Generation of PaxB transgenic mice}

To construct the $P a x B$ transgene utilized here, three copies of mouse Pax6 lens-specific element (also known as ectoderm enhacer EE) (Williams et al., 1998) were cloned upstream of the Pax6P0 minimal promoter as described for LR-Cre mice (Kreslova et al., 2007). We used this LR (lens, retina)-module to drive the expression of PaxB and Cre cDNAs connected via an internal ribosomal entry site (IRES) (Fig. 1B). Thus we were able to obtain mRNA encoding both PaxB and Cre recombinase in the same cell. To spatially and temporally define the region in which the transgene is active, we employed the Rosa26R reporter line (Soriano, 1999), in which Cre-mediated recombination results in the activation of $\beta$ galactosidase activity. In order to determine more precisely when the PaxB transcription starts we conducted whole-mount RNA in situ hybridisation tests with a PaxB riboprobe. A strong staining was observed as early as E9.5 in the presumtive lens ectoderm and neuroectoderm of the transgenic embryos (Fig. 1 C,C',C"). At E10.5 strong PaxB expression was observed in the lens pit and weaker staining in the prospective neuroretina (Fig. 1 D, D',D"). Moreover at this stage lens invagination was delayed in the transgenic embryos compared to the wild-type embryos (data not shown). $\beta$-galactosi-

E17.5
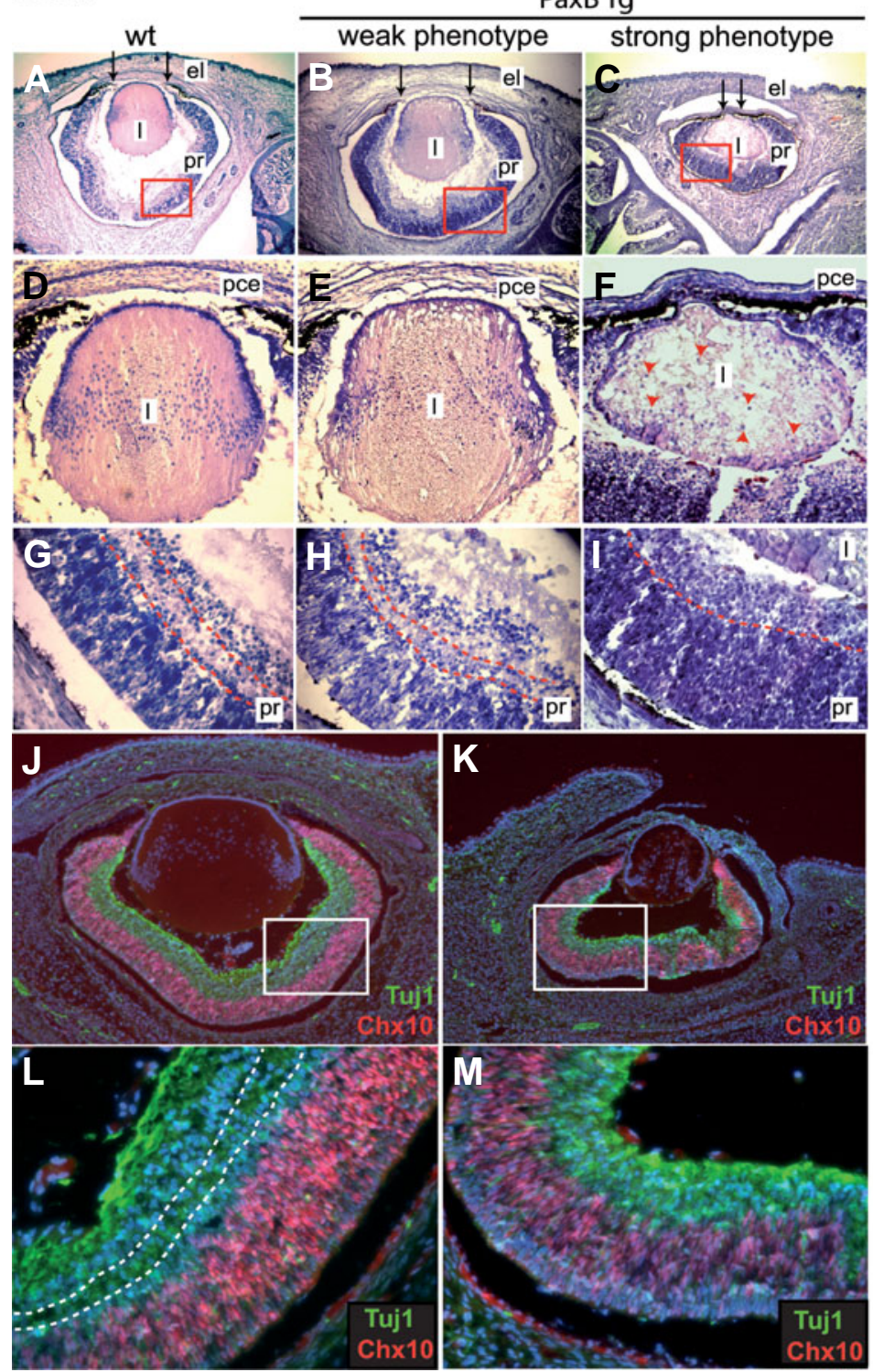

Fig. 3. Lens and retina defects detected at E17.5 in PaxB transgenic mice. Cryosections of transgenic and wild-type embryos at E17.5 were stained with hematoxylin and eosin (A-I). In addition to a smaller lens and whole eye size, there were several nuclei and vacuoles visible throughout the lens of the "strong" phenotypes (F) (marked with red arrowheads), and the diameter of the pupil was reduced in the transgenic mice (C) (marked with black arrows). The immunoreactivity of $V s \times 2$ (Chx10) (red) and $\beta$-tubulin (Tuj1, green) was compared in the developing retina of wild-type $(\mathbf{J}, \mathbf{L})$ and transgenic mice with strong phenotypes (K,M). Cell nuclei were stained with DAPI (blue). Higher magnification of the red $(\mathbf{G}, \mathbf{H}, \mathbf{I})$ and white $(\mathbf{L}, \mathbf{M})$ boxed areas reveal the difference in lamination and and thickness of the presumptive retina.

dase staining resulting from the Cre activity of the transgene was first observed in the area of the presumptive lens and surrounding head surface ectoderm of E10.5 transgenic embryos (Fig. $\left.1 \mathrm{~F}, \mathrm{~F}^{\prime}\right)$. At this stage the strongest expression was detected in the lens vesicle; weaker signal was visible in the presumptive retina and surface ectoderm (Fig. 1F"). At E13.5 both the maturing lens and the 
presumptive retina revealed intensive $\beta$-galactosidase staining and mosaic expression was detected in the presumptive RPE and cornea (Fig. $\left.1 \mathrm{H}, \mathrm{H}^{\prime}, \mathrm{H}^{\prime \prime}\right)$.

\section{Phenotype of PaxB transgenic mice}

The onset and the phenotypic consequences of PaxB expression in the eye were investigated at the histological level throughout embryonic development starting from day E10.5 (Fig. 2 A,B,C). At E10.5 the lens pit appeared normal both in wild-type and PaxB transgenic embryos. The first manifestation of abnormal eye development was observed at E11.5. The transgenic lens vesicle was smaller and the elongation of lens fibers was delayed (Fig. 2 E,F) compared to control embryos (Fig. 2D). We observed a phenotypic variability even within a single line of transgenic mice. This phenomenon is most likely a result of small stochastic differences in the transgene expression among individual transgenic embryos and an extreme dosage sensitivity of eye tissue to the level of Pax6 gene (see bellow for explanation). Interestingly, the stronger the expression of the transgene (Fig. $2 \mathrm{H}, \mathrm{I}, \mathrm{N}, \mathrm{O}$ ), the more affected was eye development (Fig. 2 E,F,K,L). Based on these observations we sorted the transgenic mice into weak and strong phenotypes. All the subsequent stages of lens development were morphologically abnormal in the transgenic embryos (Fig. 2 Q,R). At E17.5, the transgenic mice had smaller eyes with disrupted lenses and open eyelids (Fig. 2 S, T,U). Adult mice appeared microphthalmic (Fig. 2V) compared to wild-type littermates (Fig. 2W). Dissected eyes were smaller and revealed several abnormalities (Fig. $2 \mathrm{X}, \mathrm{Y}$ ); furthermore eyes from one individual differed side-by-side (data not shown). Eyes of E17.5 wild-type and PaxB transgenic mice were also analyzed at the histological level (Fig. 3 A,B,C). The strong phenotypes had a much smaller, misshapen lens connected with the presumptive cornea (Fig. 3 C,F). Moreover there were many nuclei and vacuoles visible throughout the transgenic lens (Fig. 3F) compared to the wildtype lens which had nuclei confined to the equatorial layer (Fig. 3D). The diameter of the pupil was reduced in the severely affected transgenic mice (Fig. 3C, marked with black arrows). There were also differences in lamination and distribution of retinal progenitor cells in the transgenic retinas (Fig. $3 \mathrm{I}, \mathrm{K}, \mathrm{M}$ ) compare to the wild-type retinas (Fig. $3 \mathrm{~J}, \mathrm{~L}$ ). No phenotype was observed in the negative control transgenic line in which the same LR regulatory module was used to drive Cre expression (Supplementary Fig. 1). Together, these observations demonstrate that the expression of $P a x B$ strongly influences normal development of the lens, cornea and retina.

\section{Impaired regulation of early lens development in PaxB trans- genic mice}

The lens defects in PaxBtransgenic mice prompted us to examine the expression of FoxE3 and Mab21/1, since mice with mutated FoxE3 or Mab21/1 have phenotypes that are similar to those of the PaxB transgenic mice, namely, a rudimentary lens and persistent connection between lens and cornea (Blixt et al., 2000; Yamada et al., 2003; Medina-Martinez et al., 2005). Moreover, it is known that the early expression of FoxE3 and Mab21/1 is downregulated in Sey mice and therefore dependent on Pax6 gene dosage (Yamada et al., 2003; Blixt et al., 2007).

FoxE3 expression was observed in the lens placode and in the brain of wild-type embryos (Fig. 4A). By contrast, FoxE3mRNA was not detected in the area of the invaginating lens in $P a x B$ transgenic mice (Fig. 4A'). However, FoxE3 expression in the PaxB transgenic brain was indistinguishable from the control littermate. AtE11.5 there was notably weaker FoxE3 staining in the lens remnant of the PaxB transgenic mice (Fig. 4B'), compared to the wild-type embryo (Fig. 4B). Similar reductions were observed for Mab21/1 mRNA levels (Fig. 4 C, $\mathrm{C}^{\prime}$ ).
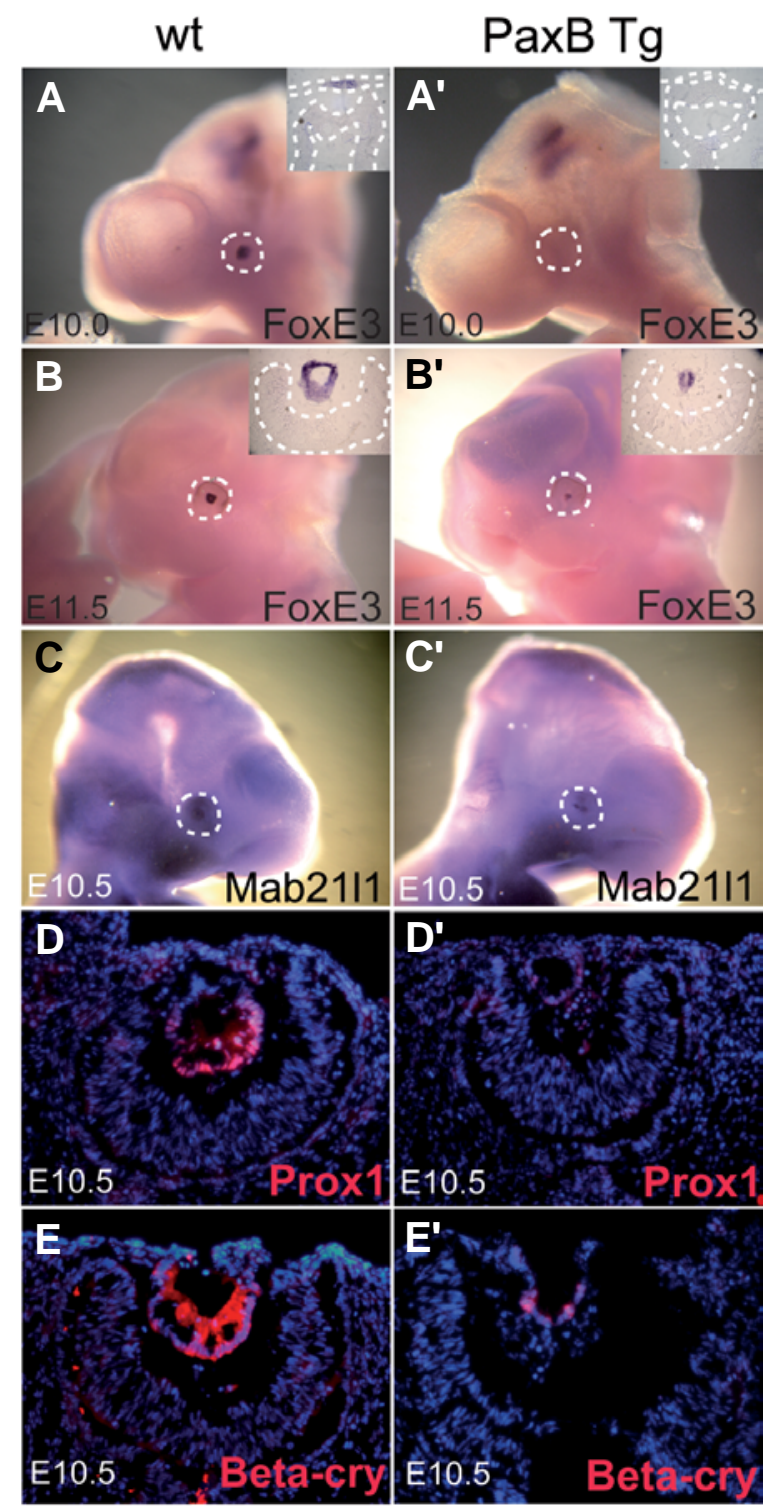

Fig. 4. Downregulation of lens specific markers in PaxB transgenic mice. Whole mount RNA in situ hybridization (A-C') and RNA hybridization in sections (insets in $\left.A-B^{\prime}\right)$ at E10.0 (A,A'), E10.5 (C, $\left.\mathbf{C}^{\prime}\right)$ and E11.5 $\left(\mathbf{B}, \mathbf{B}^{\prime}\right)$ in wild-type $(\mathbf{A}, \mathbf{B}, \mathbf{C})$ and $\mathrm{Pax} \mathbf{B}$ transgenic $\left(\mathbf{A}^{\prime}, \mathbf{B}^{\prime}, \mathbf{C}^{\prime}\right)$ embryos with probes for FoxE3 (A-B') and Mab21/1 (C,C'). Immunohistochemistry using anti-Prox 1 (D,D') and anti- $\beta$-crystallin (E,E') antibodies on sections from E10.5 embryos. Sections were counterstained with DAPI(D-E'). At E10.0 FoxE3 was expressed in the presumptive lens ectoderm and in a restricted area of the brain (A). FoxE3 MRNA was not detected in the ocular surface ectoderm of $\mathrm{PaxB}$ transgenic mice, whereas staining in the brain was unaffected ( $\left.\mathbf{A}^{\prime}\right)$. At E11.5 low expression of FoxE3 was seen in the lens remnant of $\mathrm{Pax} B$ transgenic mice (B'). A similar reduction was observed for Mab2111 mRNA (C') and for immunoreactivity for Prox1 (D') and $\beta$-crystallin (E') in the transgenic mice. Note the delayed formation of the lens pit in the PaxB transgenic mice ('D',E'). 
To investigate if the decrease in FoxE3 and Mab21/1 levels reflected a general delay in activation of lens markers, we examined the expression of Prox1, which is essential for lens fiber differentiation and cell cycle exit (Wigle et al., 1999), and of $\beta$-crystallin, which is a marker of lens fibers differentiation. At E10.5 the lenses of wildtype mice showed high immunoreactivity of Prox 1 and $\beta$-crystallin (Fig. $4 \mathrm{D}, \mathrm{E})$ whereas the PaxB transgenic mice had negligible staining for those markers (Fig.4 D',E'). Other lens markers were tested by immunohistochemistry at E11.5 (Supplementary Fig. 2) to further clarify the character and differentiation status of the lens of PaxB transgenic mice. Both Prox1 and c-Maf were abundant in the lens of control mice whereas their expression in the PaxB transgenic

E10.5
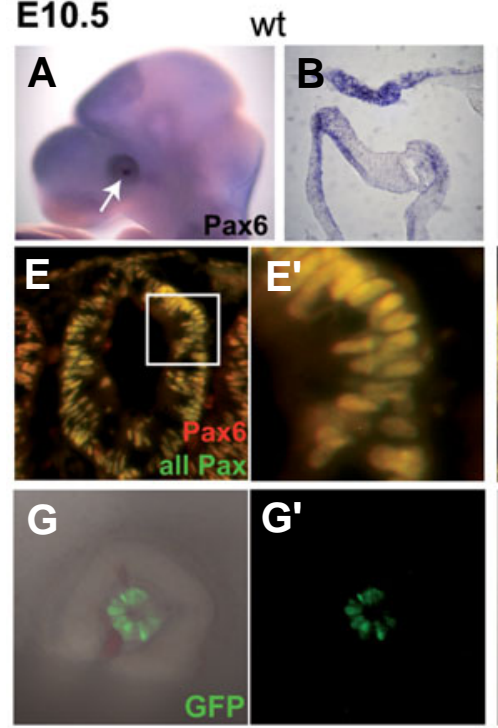

I

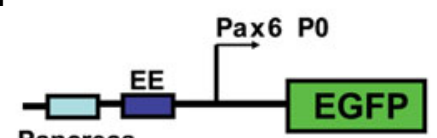

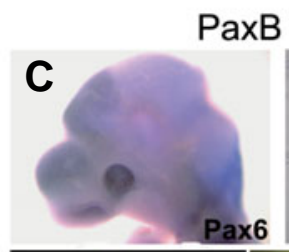
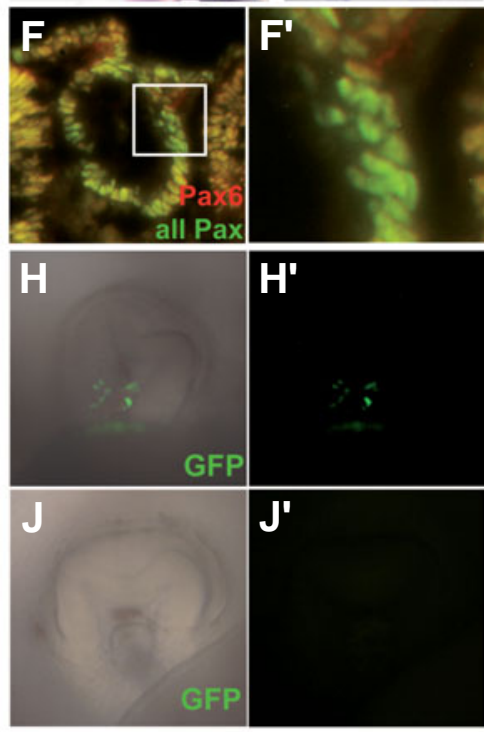

mice was much weaker (Supplementary Fig. 2 A, $\left.A^{\prime}, B, B^{\prime}\right)$. Positive immunoreactivity in $P$ ax $B$ transgenic mice was detected for $\alpha$-, $\beta$-and $\gamma$-crystallin proteins (Supplementary Fig. 2C'-F') and MIP26 (Supplementary Fig. 2G') although in strikingly lower amount compared to wild-type mice (Supplementary Fig.2 C-G).

\section{Effect of PaxB is independent of Six 3 and Meis homeoproteins}

$P a x B$ transgenic mice were tested for endogenous Pax 6 and $P a x 2$ expression because these genes are necessary for spatial specification of eye territories (Schwarz et al., 2000). E10.5 PaxB transgenic mice revealed no difference in either Pax6 or Pax2 staining (Supplementary Fig. 3B,D) compared to wild-type mice (Supplementary Fig. 3 A,C) consistent with a normal optic cup/optic stalk boundary. Next, we examined expression of the homeobox gene Vsx2 (Chx10) (Liu et al., 1994), the earliest known marker specifically expressed in the proliferating retinal progenitor cells and subsequently in the bipolar cells (Burmeister et al., 1996). Control and PaxB transgenic neuroretina did not show any difference in Vsx2 (Chx10) pattern (Supplementary Fig. 3 E,F).

To further explore the molecular basis for lens defects in $P a x B$ transgenic embryos, we investigated the expression of Six3, Meis1 and Meis2 proteins, known transcription factors which direct lens development. Conditional knockout of Six3 in the presumptive lens ectoderm disrupts lens formation and is accompanied by downregulation of Pax6 (Liu et al., 2006). Meis1 and Meis2 are direct regulators of Pax6 expression in prospective lens ectoderm (Zhang et al., 2002). The expression of all these transcription factors did not change in the E10.5 PaxB transgenic eyes (Supplementary Fig. $3 \mathrm{H}, \mathrm{J}, \mathrm{L}$ ), compared to wild-type eyes (Supplementary Fig. $3 \mathrm{G}, \mathrm{I}, \mathrm{K})$.

\section{PaxB downregulates endogenous Pax6 expression in developing lens}

Our data indicated that $P a x B$ expression downregulates genes encoding transcription factors downstream of the Pax6 regulatory network for lens development and disrupts lens development but does not affect genes upstream of

\section{K}

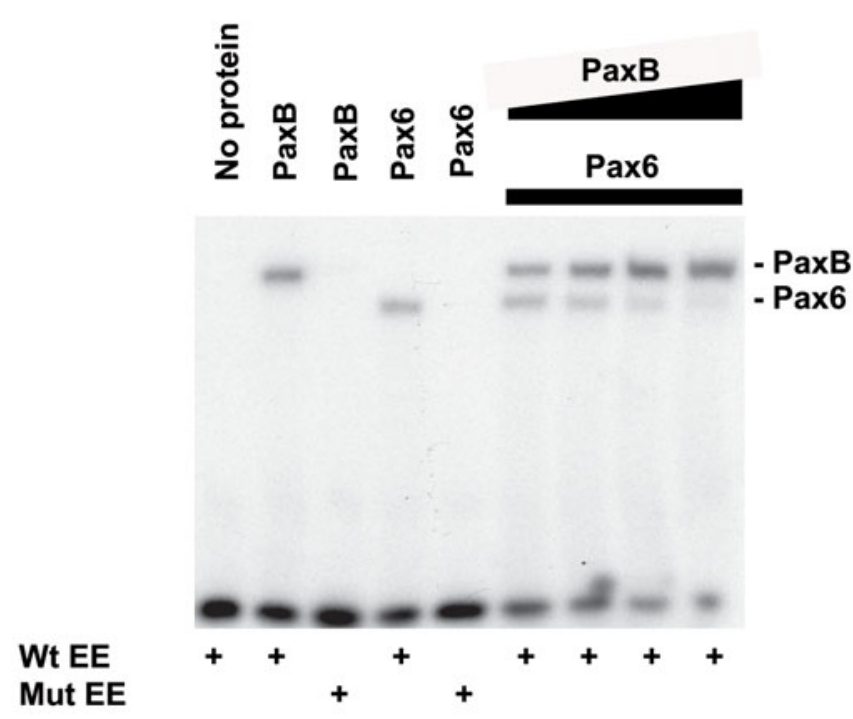

Fig. 5. Decreased levels of endogenous Pax6 in the PaxB transgenic lens. All stainings were performed on E10.5 wild-type (A,B,E, $\left.\mathbf{E}^{\prime}, \mathbf{G}, \mathbf{G}^{\prime}\right)$ and PaxB transgenic (C,D, $\left.\mathbf{F}, \mathbf{F}^{\prime}, \mathbf{H}, \mathbf{H}^{\prime}, \mathbf{J}, \mathbf{J}^{\prime}\right)$ embryos. Whole mount Pax6 RNA in situ hybridization (A-D) and RNA hybridizations were conducted using sections of developing eyes (B,D). Lower levels of Pax6 mRNA were found in the presumtive lens ectoderm in PaxB transgenic mice (C,D). Immunohistochemistry was performed on cryosections (E-F') using Pax6 (Covance; red) and anti-paired domain (staining all Pax genes; green) antibodies ( $E, F$; white boxed areas was magnified in in $\left.E^{\prime}, F^{\prime}\right)$. The lens vesicle and surface ectoderm of $\mathrm{Pax} B$ transgenic mice $\left(\mathbf{F}^{\prime} \mathbf{F}^{\prime}\right)$ revealed cells stained more in green than in red, which could be due to lower levels of endogenous Pax6 expression [compare with wild-type lens vesicle (E,E')]. In order to test if PaxB repressed expression of Pax6 we employed transgenic mice EE-EGFP (MD63) in which EGFP was driven by the lens specific ectoderm enhancer (EE) and pancreas specific Pax6 enhancer (I). EGFP fluorescence readily observed in wild-type embryos (G,G') was decreased $\left(\mathbf{H}, \mathbf{H}^{\prime}\right)$ or absent $\left(\mathbf{J}, \mathbf{J}^{\prime}\right)$ in PaxB transgenic embryos despite the presence of the lens tissue. Binding of mouse Pax6 and Tripedalia PaxB proteins to the wild-type but not mutated Pax6 autoregulatory element located within EE. Increasing amounts of PaxB protein are able to displace Pax6 from the autoregulatory element (K). 

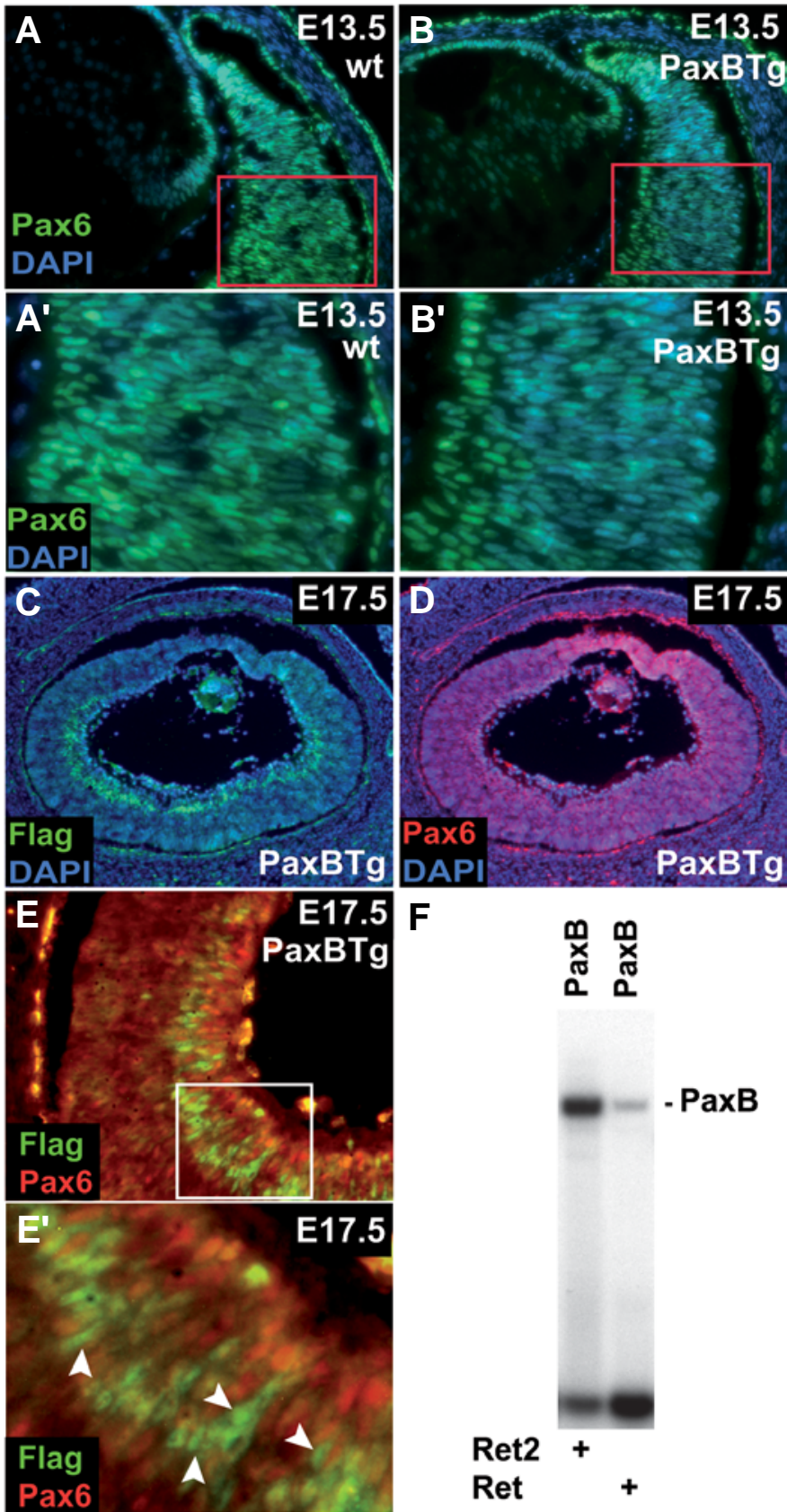

\section{$F$}

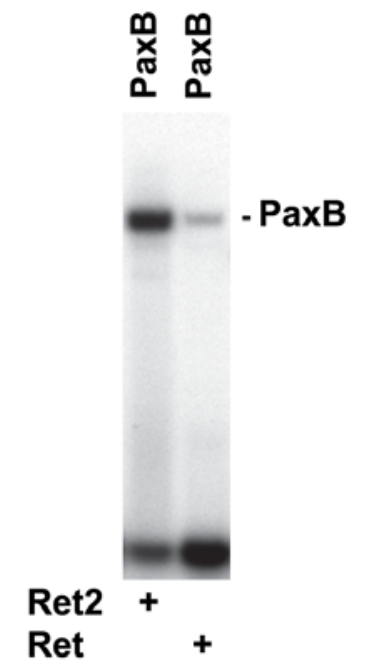

Fig. 6. Pax6 is repressed in the PaxB expressing cells. The immunohistochemistry on tissue sections using anti-Pax6 antibody (green) at E13.5 $(\mathbf{A}, \mathbf{B})$ (area in red rectangle was magnified in $\left.A^{\prime}, B^{\prime}\right)$. All sections were counterstained with DAPI. Pax6 expression in the retina of PaxB transgenic animals (B, $\mathbf{B}$ ') was diminished (visible as a weaker green staining (Pax6) as compared to wild-type retinas $\left.\left(\mathbf{A}, \mathbf{A}^{\prime}\right)\right)$. Cryosections from $\mathrm{PaxB}$ transgenic mice from stage E17.5 (C-E') were stained with Flag (PaxB; green), Pax6 (DSHB; red) and DAPI (blue). A transgenic eye section at E17.5 revealed strong Flag (PaxB) immunoreactivity in the inner nuclear layer of both the central and distal retina $(\mathbf{C})$ relative to Pax6 expression (D). The area within the white rectangle was magnified in (E,E'). White arrowheads point to cells expressing Flag (PaxB, green) (E'); red color (Pax6) was absent in these cells, i.e. Pax6 staining was diminished in PaxB positive cells. (F) Binding of Tripedalia PaxB protein to Pax6 recognition sites Ret and Ret2 located within the mouse Pax6 retinalspecific $\alpha$-enhancer.
Pax6 within the pathway. We tested if $P a x B$ expression directly influences the expression of an endogenous Pax6. First we examined Pax6 expression by RNA in situ hybridization at E10.5. The staining for Pax6 mRNA in the lens placode was markedly reduced in the $P a x B$ transgenic embryos (Fig. 5 C,D) compared to wild-type embryos (Fig. 5 A,B). We next stained for Pax6 imunohistochemically using Pax6 specific and paired domain (PD) specific antibodies. The latter enabled us to detect all members of Pax family proteins (including PaxB, Pax6 and Pax2). At E10.5, Pax6 is the only Pax gene expressed in the wild-type lens vesicle; Pax2 at this timepoint is expressed exclusively at the optic vesicle/optic stalk boundary (Schwarz et al., 2000). As expected, all the cells within the wild-type lens vesicle were stained by both anti-Pax6 (red) and anti-PD (green), which resulted in yelow staining (Fig. $5 \mathrm{E}, \mathrm{E}^{\prime}$ ). In contrast, we only detected PaxB together with Pax6 in the PaxB transgenic lens using anti-PD antibody (green) (Fig. 5 F,F'). We observed several green cells among yellow cells in the $P a x B$ transgenic lens vesicle (Fig. 5 F,F'), indicating a decline of endogenous Pax6 expression in the cells expressing PaxB protein. Combined, our data suggest that endogenous Pax6 expression is downregulated in the PaxBexpressing cells of the lens vesicle.

Pax6 expression during lens development is regulated by the ectoderm enhancer (EE) (Williams et al., 1998; Kammandel et al., 1999; Xu et al., 1999). To test if PaxB could downregulate Pax6 via this element, we employed another transgenic mouse EEEGFP (MD63), where the EE element of Pax6 was used to drive EGFP to the developing lens (Fig. 5I). After crosssing the EEEGFP (MD63) and PaxB transgenic mice, we assessed EGFP levels at E10.5. EGFP intensity was decreased or completely abrogated in the lens of PaxB transgenic mice (Fig. $5 \mathrm{H}^{\prime} \mathrm{H}^{\prime}, \mathrm{J}, \mathrm{J}^{\prime}$ ) as compared to the control mice (Fig. 5G,G'). These results support the idea that PaxB downregulates Pax6 gene expression and suggest that this suppression acts through the ectoderm enhancer (EE) of Pax6.

Since Pax6 expression in the lens placode involves an autoregulatory mechanism (Aota et al., 2003) we tested if $P$ axB is able to bind to the Pax6 autoregulatory binding site within the EE. As shown in Fig. 5K, PaxB binds to this autoregulatory site and is able to displace Pax6 protein from it. Our data thus suggest that in lens PaxB suppresses Pax 6 expression presumably through a direct competition for the Pax6 autoregulatory element within EE.

\section{PaxB influences the development of neuroretina in the PaxB transgenic mice}

In addition to the lens phenotype, there is also a phenotype in the neuroretina of the $P a x B$ transgenic mice. As mentioned above PaxB expression driven by three copies of EE of the Pax 6 gene was detected in the presumptive retina as early as E9.5 (Fig. 1C") and later, at E13.5, in the distal retina (Fig. 2O). At E13.5 reduced Pax6 expression was detected in PaxB transgenic retina (Fig. 6 $A, B)$. At perinatal stages the expression of $P a x B$ transgene was detected in the inner nuclear layer of both the central and distal retina (Fig. 6C). We believe that this region may represent an abberant expression domain of the 3xEE regulatory module. Such interpretation is consistent with the observation that weak expression of Le-Cre transgene (Ashery-Padan et al., 2000) is present in the retina exemplified by the fact that in Le-Cre; Z/AP double transgenic mice the recombination was detected in the 

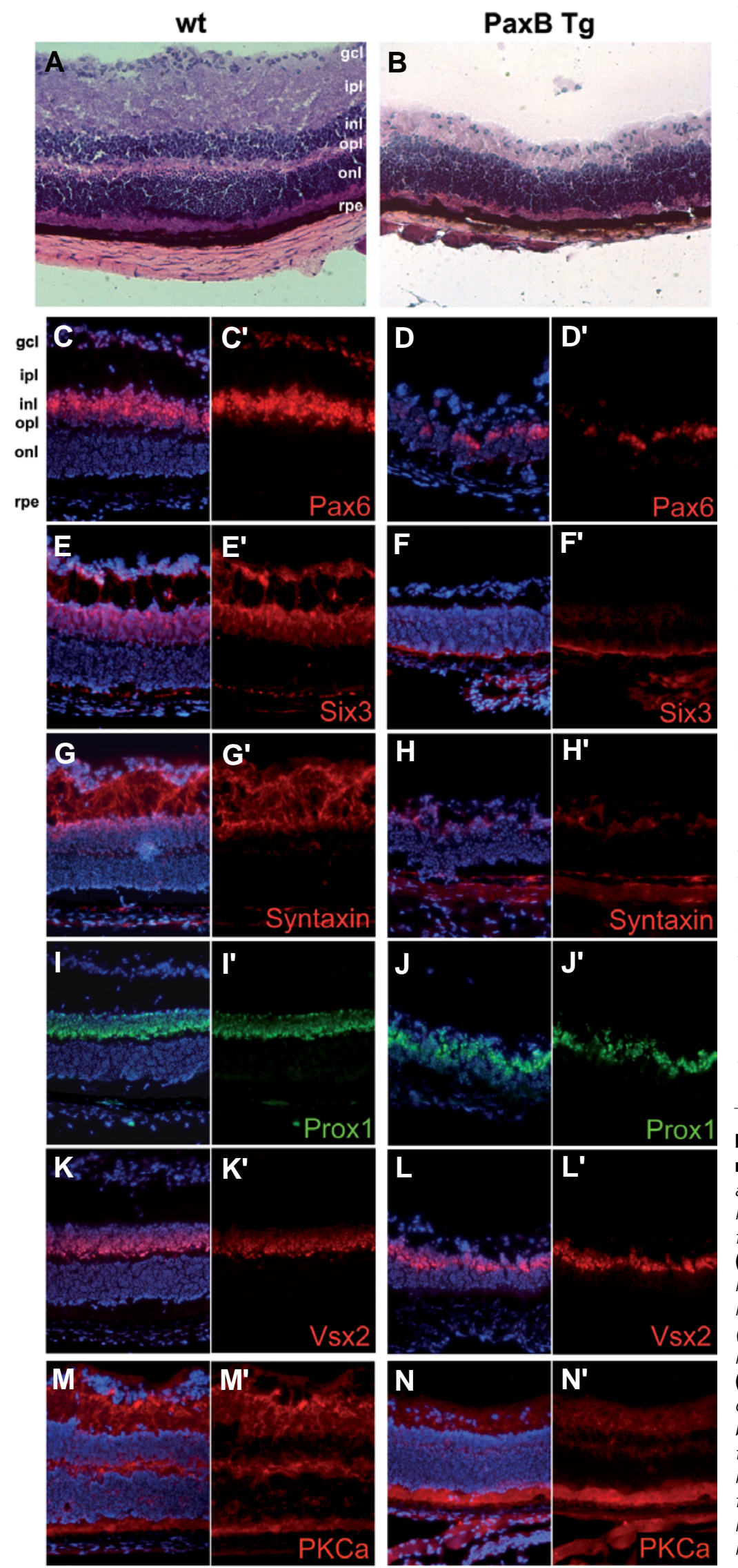

vitreal side of the P4 retina (Davis-Silberman et al., 2005). At E17.5 histology and immunoreactivity of the PaxB transgenic retina (Fig. $3 \mathrm{I}, \mathrm{K}, \mathrm{M}$ ) were markedly different from the retina of wild-type animals (Fig. $3 \mathrm{G}, \mathrm{J}, \mathrm{L}$ ). To further characterize PaxB expressing cells we took advantage of a FLAG epitope present in the PaxB transgene. Strong staining with anti-FLAG antibody was observed at $E 17.5$ in subsets of cells within the inner nuclear layer (INL), both in the distal and central retina of the PaxB transgenic mice (Fig. 6C). Moreover double-staining with anti-Pax6 antibody (red) showed a decrease in endogenous Pax6 expression in the cells expressing the $P a x B$ transgene (green) (Fig. 6E,E'). Pax6 is known to regulate its own expression through binding to retina-specific $\alpha$ enhancer located in intron 4 of Pax6gene (Schwarz et al., 2000). We tested if $P a x B$ is able to bind to Ret and Ret2 binding sites described previously (Schwarz et al., 2000). As shown in Fig. 6F, PaxB binds to both of these elements suggesting that $\mathrm{PaxB}$ suppresses Pax 6 expression presumably through a direct competition.

We next compared the histology of adult wild-type and PaxB transgenic retinas. Compared to the well-organized wild-type retina (Fig. 7A), the retina of $P a x B$ transgenic mice was thinner with no proper lamination and the outer plexiform layer (OPL) was missing (Fig. 7B). To investigate the expression of cell-type specific markers we performed several immunohistochemistry stainings on one month old PaxB transgenic and control retinas. First we investigated expression of Pax6, which is a marker of both amacrine and retinal ganglion cells (RGCs) and some horizontal cells (Marquardt et al., 2001). The number of Pax6 possitive cells was markedly decreased in the transgenic retina (Fig. 7 D,D'); few cells were stained in the fused remnant of inner- (INL) and outer nuclear layer (ONL) and no staining occured in the GCL (compared to wild-type retina Fig. 7 C,C'). Six3, a homeobox transcription factor specifying amacrine cells in the INL and displaced amacrines in the GCL (Oliver et al., 1995), was absent in the transgenic (Fig. 7 F,F') but not the wild-type retina (Fig.7E,E'). The immunoreactivity of another marker for all amacrine cells, syntaxin (HPC-1), was undetect-

Fig. 7. Characterization of adult retina in PaxB transgenic mice. Cryosections of adult retina from the wild-type (left panels) and PaxB transgenic mice (right panels) were stained either with hematoxylin and eosin $(\mathbf{A}, \mathbf{B})$ or with antibodies against the following proteins: Pax6 (Covance, C-D'), Six3 (E-F'), syntaxin (G-H'), Prox1 (I-J'), Vsx2 (Chx10) (K-L') and PKC $\alpha$ (M-N'). The nuclei were counterstained with DAPI. The PaxB transgenic retina was notably thinner with no proper lamination (B); outer (onl) and inner (inl) nuclear layers were not separated. Immunohistochemistry showed reduced staining of Pax6 (D,D'), Six3 $\left(\mathbf{F}, \mathbf{F}^{\prime}\right)$ and syntaxin $\left(\mathbf{H}, \mathbf{H}^{\prime}\right)$ indicating the absence of amacrine cells. The number of bipolar and horizontal cells did not appear to be affected in the PaxB transgenic retina as revealed by detection of Vsx2 (Chx10), Prox 1 and PKC $\alpha$. Abbreviations for distinct retinal layers described in this and subsequent figures are as follows: gcl-ganglion cell layer, ipl-inner plexiform layer, inl-inner nuclear layer, opl-outer plexiform layer, onl-outer nuclear layer, rpe-retinal pigment epithelium. 
able in the transgenic retina (Fig. $7 \mathrm{H}, \mathrm{H}^{\prime}$ ). The levels of Prox1, normally found in horizontal, bipolar and some amacrine cells (Dyer et al., 2003), and bipolar cell markers Vsx2 (Chx10) (Burmeister et al., 1996) as well as PKC $\alpha$, were comparable between transgenic and control mice (Fig. 7 I-N'). In addition to Pax6, three other markers were used for staining of RGCs; Brn3b (Xiang et al., 1995), OLF1 (Davis and Reed, 1996) and $\beta$-tubulin (TUJ1). No immunoreactivity was observed for any of these proteins in the PaxB transgenic mice (Fig. 8 A-F'). The presence of photoreceptors was examined by using several markers: CRX (cone-rod homeobox containing gene) (Zhu and Craft, 2000), NR2e3 (protoreceptor specific nuclear receptor), M-opsin (M-cone photoreceptors) (Zhu et al., 2003), S-opsin (Scone photoreceptors) (Zhu et al., 2003), rhodopsin (rodphotoreceptors), arrestin (rod-photoreceptors), GRK1 (rhodopsin kinase) (Results are summarized in Supplementary Fig. 4). Of all of these tested markers only rhodopsin was reduced in the PaxB transgenic retina (Supplementary Fig. 4 K-L').

Taken together, our data suggest that amacrine cells and RGC's were missing in PaxB expressing retinas. To test whether the absence of amacrine cells was due to reduced cell numbers in the INL of the transgenic retina, we sought the presence of amacrine cells using the specific markers Meis2, Calretinin, GAD65/67 (glutamic acid decarboxylase) and GlyT-1 (glycine transporter 1). Expression of homeodomain-containing transcription factor Meis2 was recently described in a subpopulation of GABAergic amacrine cells (Bumsted-O'Brien et al., 2007). GABAergic amacrine cells also express GAD65/67 (Haverkamp and Wassle, 2000). Calretinin (calcium-binding protein) selectively binds A2 cells which is the most common subtype of amacrines (MacNeil and Masland, 1998). Glycinergic amacrine cells were detected using Glyt-1 antibody. None of these markers were observed in the PaxB transgenic retina (Fig. 8 G-N').

In summary, we provide evidence that endogenous expression of Pax6 is suppressed by $\mathrm{PaxB}$ in the optic vesicle of the transgenic mice, affecting development of the retina and resulting in the absence of amacrine cells and decrease of RGC's.

\section{Discussion}

Eye development in invertebrates and vertebrates depends upon the regulated expression of Pax 6 and Pax2 (see Introduction). However, the cubozoan jellyfish $T$. cystophora, which has PaxB instead of Pax2 or Pax6, has sophisticated lens-containing eyes that share numerous

Fig. 8. PaxB expression supresses amacrine cell fate in adult retina. Cryosections of adult retina from the wild-type (left panels) and PaxB transgenic mice (right panels) were stained using antibodies against the following proteins: Brn3b (A-B'), OLF-1 (C-D'), Tuj1 ( $\beta$ tubulin, E-F'), Meis2 (G-H'), calretinin (I-J'), GAD65/67 (glutamic acid decarboxylase, K-L'), Glyt1 (glycine transporter 1, M-N'). The nuclei were counterstained with DAPI. The immunoreactivity of retinal ganglion cells was diminished in PaxB transgenic retinas (Brn3b, OLF-1 and Tuj1; gcl is marked by white arrow), although some cells remained within
the ganglion cell layer (visible with DAPI). The lack of amacrine cells in the PaxB transgenic retina was confirmed by staining with the following amacrine-subpopulation markers: Meis2 and GAD65/67 (GABAergic), Glyt1 (Glycineric) and calretinin (A2 amacrine cells).
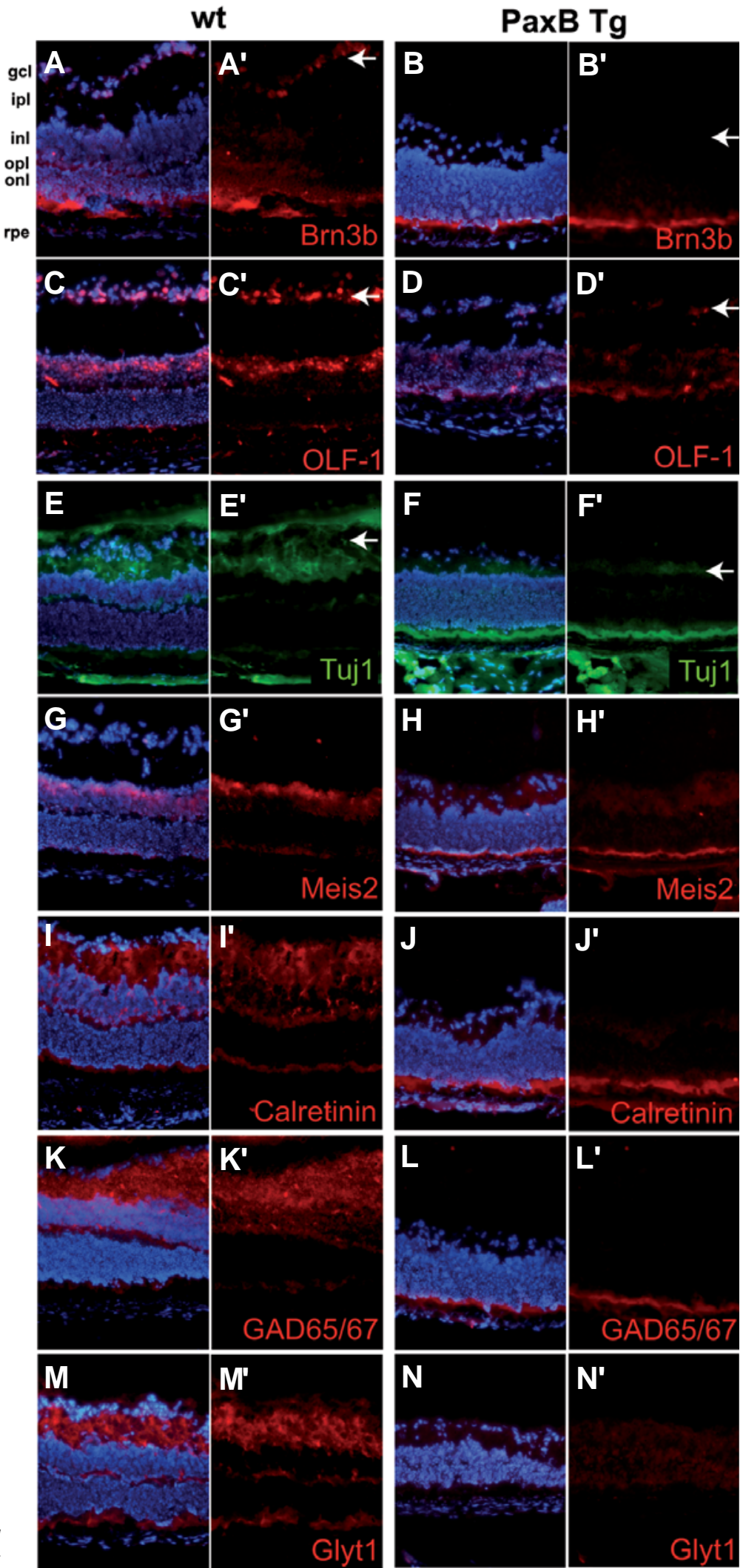
characteristics with vertebrate eyes (Kozmik et al., 2008). Jellyfish PaxB has a Pax2-like paired domain and octapeptide and a Pax6-like homeodomain potentially giving it functional properties of both Pax2 and Pax6. Indeed, it has been shown that jellyfish $P a x B$ can induce ectopic eyes, like Pax6, and can substitute for Pax2 in Drosophila (Kozmik et al., 2003); moreover, PaxB is expressed in the jellyfish eye (Kozmik et al., 2003). In the present study we found that unlike its combined Pax2 and Pax6-like properties in Drosophila, PaxB neither directs eye development nor substitutes for Pax6 for eye development in transgenic mice. Indeed, PaxB expression in transgenic mice creates microphthalmic eyes with abnormal lens and retinal phenotypes. In the $P a x B$ transgenic mice $P a x B$ is co-expressed with the Cre recombinase in the lens and retina. It is highly unlikely that any observed phenotype is due to Cre expression since none of these defects was detected in the LR-Cre mice (Kreslova et al., 2007) (Supplementary Fig. 1).

Our data indicate that one of the reasons why $P a x B$ disrupts mouse eye development is that it suppresses $P a x 6$ gene expression. PaxB suppression of Pax6 expression is consistent with the presence of a Pax6 autoregulatory site in the Pax6 EE enhancer required for lens expression (Kammandel et al., 1999; Aota et al., 2003). Moreover, the retinal $\alpha$-enhancer of Pax 6 contains autostimulatory Pax6 sites that drive Pax6 expression in the retina (Kammandel et al., 1999; Schwarz et al., 2000). Pax2 cooperates with homeodomain containing proteins Vax1 and Vax2 to repress the Pax6 $\alpha$-enhancer (Mui et al., 2005). We propose that the Pax2-like and Pax6-like structural properties of PaxB enable it to interact with the autoregulatory enhancers of the endogenous Pax6, preventing normal expression of this critical gene for eye development. Lowered levels of Pax6 are known to prevent the normal development of mouse eyes (Collinson et al., 2000; van Raamsdonk and Tilghman, 2000; Dimanlig et al., 2001). In addition, heterozygous Pax 6 mutations are responsible for the Small eye (Sey) phenotype in mice and for aniridia and Peters' anomaly in humans (Hill et al., 1991; Ton et al., 1991; Glaser et al., 1992; Hanson et al., 1994). Likewise, increased levels of Pax6 were shown to result in various eye abnormalities (Schedl et al., 1996; Kim and Lauderdale, 2006; Kim and Lauderdale, 2008; Manuel et al., 2008). However, none of the phenotypes described previously is identical to the phenotype generated by misexpression of PaxB.

The phenotypes in the abnormal eyes of the PaxB transgenic mice support the idea that $\mathrm{PaxB}$ suppresses endogenous $P a x 6$ expression in lens. First, the present findings that the genes acting downstream of Pax6 during lens development encoding Mab2111, FoxE3, Prox1 and crystallins are reduced, while expression of Six3, Meis 1 and Meis2, all genes upstream of Pax6, are unaffected in the lenses of the PaxBtransgenic mice. Second, targeted disruption of FoxE3, whose expression critically depends on Pax6 (Blixt et al., 2007) results in lens defects resembling the phenotype of PaxB transgenic mice (Blixt et al., 2000; Medina-Martinez et al., 2005). Moreover delayed lens development in PaxB transgenic mice resembled the smaller lens pit or vesicle of Pax6 Sey/+ heterozygote and Pax6 ${ }^{\triangle \mathrm{EE} / \Delta \mathrm{EE}}$ mice (van Raamsdonk and Tilghman, 2000; Dimanlig et al., 2001). Finally, EE contains a Pax6 autoregulatory site (Aota et al., 2003) which can be supressed either by direct binding of $\mathrm{PaxB}$ or by lower levels of Pax6. These data suggest that $P a x B$ suppresses the expression of Pax6 in the developing lens, making Pax6 dosage insufficient for normal lens proliferation and induction of downstream transcription factors (FoxE3, Mab21l1 and Prox1) and crystallin genes. Lens degeneration due to low Pax6 levels has been shown using different mouse models (Collinson et al., 2000; van Raamsdonk and Tilghman, 2000; Dimanlig et al., 2001).

Pax6 is the only Pax protein known to be expressed in the mouse lens. The situation is different in the retina. At early stages of eye development Pax2 is co-expressed with Pax6 in the optic vesicle, and during optic nerve formation $P a x 2$ becomes resticted to the ventral neuroretina surrounding the closing optic fissure (Nornes et al., 1990; Baumer et al., 2003). The presence of $P a x 2$-binding sites on the retina enhancer of the Pax6gene and co-transfection experiments revealed reciprocal inhibition of Pax6 enhancer activity by Pax2 (Schwarz et al., 2000). It is unlikely, however, that the retina phenotype observed in $P a x B$ transgenic mice is solely due to the downregulation of Pax6. Conditional deletion of the Pax 6 gene using $\alpha$-Cre results in the exclusive generation of amacrine cells (Marquardt et al., 2001) while PaxB transgenic mice exhibit a complete depletion of amacrine cell population in retina (see below). Therefore it appears that $\mathrm{PaxB}$ is able to elicit a dominant phenotype in the retina by means of its modified DNA-binding specificity and/or altered transactivation potential.

It follows that the distinct molecular properties of Pax6 are required for normal mouse eye development and this role of Pax6 can not be substituted by an ancestral PaxB protein. A comparison of properties between $\mathrm{Pax} 6$ and $\mathrm{PaxB}$ transcription factors gives a partial hint towards the molecular mechanism underlying the observed phenotype. Both PaxB and Pax6 have two independent DNA-binding domains, the paired domain and the paired-type homeodomain, respectively. Pax6 and PaxB paired domains interact with very similar DNA sequences although some differences in specificity exist. In particular, three amino acids (at positions 42, 44, and 47) within the Nterminal half of paired domain are responsible for the difference in the DNA-binding specificities between $\mathrm{Pax} 6$ and $\mathrm{PaxB} / \mathrm{Pax} 2 /$ 5/8 subfamilies (Czerny and Busslinger, 1995; Kozmik et al., 2003). However, so far these amino acid differences have been shown to restrict the DNA-binding specificity of Pax6 rather than expand it (Czerny and Busslinger, 1995; Kozmik et al., 2003). This opens up a formal possibility that in the PaxB transgenic mice $\mathrm{PaxB}$ inappropriately regulates retinal genes not normally regulated by Pax6. Unlike the situation with paired domain, the DNA-binding specificity of paired-type homeodomain of $\mathrm{Pax} 6$ and $\mathrm{PaxB}$ is likely shared as it is defined as a palindromic sequence composed of two inverted TAAT motifs. Both Pax6 and PaxB act as transcriptional activators when tested in the cell culture system. Pax6 contains a Cterminal transactivation domain composed of short regions that act in synergy with each other (Tang et al., 1998). PaxB includes in its $C$ terminus adjacent activation and inhibitory domains, a characteristic of Pax2/5/8 (Dorfler and Busslinger, 1996; Lechner and Dressler, 1996; Kozmik et al., 2003). The nature of co-factors interacting with the inhibitory region is unknown. However, the inhibitory region of $\mathrm{Pax} 2 / 5 / 8$ does not seem to be an autonomous unit as it is unable to impose an inhibition on a heterologous activation domain (Dorfler and Busslinger, 1996) suggesting that it might function through 
intramolecular interaction within an intact $\mathrm{Pax} 2 / 5 / 8$.

The only well-recognizable structural element outside of the DNA binding domains is the octapeptide motif which mediates efficient interaction of $\mathrm{PaxB}$ and $\mathrm{Pax} 2 / 5 / 8$ with groucho corepressors (Eberhard et al., 2000; Kozmik et al., 2003). By this mechanism Pax $2 / 5 / 8$ proteins are converted from transcriptional activators to transcriptionl repressors (Eberhard et al., 2000). Combined, our data suggest that groucho-mediated repression by $\mathrm{PaxB}$ at sites normally bound by wild type Pax6 may be responsible, at least in part, for the observed retinal phenotype (loss of amacrine cells). A new transgenic line expressing a modified Pax6 (including an artificially fused octapeptide motif) will be necessary to provide a more definitive evidence for such a hypothesis.

The present investigation provides evidence that amacrine and retinal ganglion cells (RGCs) were absent and/or reduced in the adult retina of $P a x B$ transgenic mice. This was consistent with downregulation of endogenous Pax 6 in the cells expressing $P a x B$ in the inner layer of the optic cup at E17.5. Moreover PaxB immunoreactivity in the developing neuroretina was observed as early at E9.5 (Fig. 1 C-D"), consistent with the retina being affected early in development. It is known that Pax6 is required for the multipotent state of retinal progenitor cells (RPCs) and that upon Pax6 inactivation in the distal retina only amacrine interneurons are generated from RPCs at the expense of other cell types (Marquardt et al., 2001). It is also known Pax6 is required for cell proliferation in the optic vesicle and for RPCs to adopt specific retinal cell fates (Philips et al., 2005; Duparc et al., 2007). Amacrine cells do not differentiate in Pax6-null optic vesicles, where the proneural gene Mash1 is expressed instead of NeuroD1 (Philips et al., 2005). For the differentiation of each retinal cell type specific transcription factors have to be co-expressed in the RPCs. As retinal neurons differentiate, they exit the cell cycle and migrate towards the inner (vitreal) side of the optic cup. Distinct members of the basic helix-loop-helix (bHLH) family of transcription factors specify the cell fate within a developing mouse retina (Livesey and Cepko, 2001). With respect to the present study it is noteworthy that Pax6 directly regulates genes encoding Ngn2, Mash1 and Math5 (Marquardt et al., 2001; Hufnagel et al., 2007). For RGC formation both Math5 and Pax6 are required (Brown et al., 2001; Marquardt et al., 2001; Wang et al., 2001; Hutcheson et al., 2005; Mu et al., 2005). RGCs are formed at late E12.5/ early E13.0 stage when they appear within a central domain of the retina and are marked by strong expression of Pax6. The early progenitor cells that co-express Math3 and NeuroD1 (Inoue et al., 2002) together with Pax6/ Six3/Prox1 (Dyer et al., 2003) or Pax6/Six3/Lim1 (Liu et al., 2000) adopt the amacrine or horizontal cell fate. Pax6 is normally expressed by both amacrine cells and RGCs in postnatal retinas (Davis and Reed, 1996). In PaxB transgenic mice we were not able to detect several markers of amacrine cells: syntaxin, calretinin, GAD65/67, which was accompanied by lower levels of Pax6, Six3 and Meis2 (Figs. 7, 8). Furthermore, RGCs (visualised with Brn3b and OLF-1 antibodies), which normally express Pax6, were reduced. Together, these data suggest that in $P a x B$ expressing mice differentiation of amacrine and retinal ganglion cells was impaired due to downregulation of endogenous Pax 6 in the cells within the central domain of neuroretina where the differentiation of RPCs takes place.

Gene swapping experiments have demonstrated functional redundancy between transcription factor family members and have indicated that spatial and temporal differences in expression of related transcription factors are often more crucial than differences in biochemical activities of the corresponding proteins. For example, in mid-hindbrain development En1 mutant phenotype was rescued by replacing En1 with closely related En2 (Hanks et al., 1995). Likewise, the Drosophila orthologue engrailed substituted for mouse En1 function in mid-hindbrain, but not in limb development (Hanks et al., 1998). In the retina, the closely related transcription factors Pou4f1 and Pou4f2 appear interchangeable in their ability to to regulate RGC differentiation if they are expressed from the Pou4f2 locus (Pan et al., 2005). An extensive functional equivalency was demonstrated for Pax2 and Pax5 during mouse development. The Pax5 minigene, when expresed from the Pax2 locus, was able to substitute for Pax2 function in the midbrain, cerebellum, inner ear and genital tracts (Bouchard et al., 2000). In addition, Pax 5 was able to rescue most but not all Pax2 mutant defects in the developing eye and kidney, that are highly sensitive to Pax2 protein dosage. Despite this redundancy between transcription factor family members, the present study shows that jellyfish $P a x B$ interferes with the function of mouse Pax6. Expression of jellyfish $P a x B$ in the lens and retinal of transgenic mice downregulated expression of endogenous Pax6, disturbed the transcriptional network regulated normally by Pax6, and yet it was unable to take over the developmental functions of Pax6 in these eye tissues. Taken together, our data suggest that, unlike the situation in Drosophila (Kozmik et al., 2003), in mice the molecular properties of Pax 2 and Pax6 are essential determinants of mouse eye development and cannot be substituted for the chimeric PaxB protein of jellyfish.

\section{Materials \& Methods}

\section{Mouse lines}

PaxB transgenic mouse was constructed by ligating three copies of the Pax6 EE (Williams et al., 1998) to the P0 minimal promoter of the Pax6 gene. This regulatory element (3xEE-P0) was fused to a cassete containing FLAG-tagged PaxB and Cre linked via IRES to generate PaxB transgenic construct. $P a x B$ transgenic mice were generated by microinjection of linearized DNA and were maintained in a C57/BI6 inbred background. Transgenic mice were identified by PCR analysis of genomic DNA from the tail. Primers used were as follows:

forward, CAACCAATGAGGGCATTGCTGGCG;

reverse, CGTTGCATCGACCGGTAATGCA (349A/349B).

Three founder mice exhibited a microphthalmic phenotype. One of them (MB05-8) was used to establish a PaxB transgenic line described here. Analysis of the Cre-mediated recombination pattern in PaxB trangenic line was performed by mating to the ROSA26R reporter line as described (Soriano, 1999). The ROSA26R mice were purchased from Jackson Lab (stock \#003309). LR-Cre line was described previously (Kreslova et al., 2007). Pax6 reporter line EE-EGFP (MD63) was constructed by ligating the $5 \mathrm{~kb}$ upstream region of Pax6 including the EE (Williams et al., 1998) to the EGFP cassete including SV40 intron/polyA sequences. EE-EGFP (MD63) transgenic mice were generated by microinjection of linearized DNA and were maintained in a C57/BI6 inbred background. Transgenic mice were identified by PCR analysis of genomic DNA from the tail using EGFP-specific primers: 
forward, ACGTAAACGGCCACAAGTTC; reverse, AAGTCGTGCTGCTTCATGTG (785A/785B).

\section{Tissue collections and histology}

Mouse embryos were obtained from timed pregnancy matings, with noon of the date that the vaginal plug was observed defined as embryonic day 0.5 (E0.5). Embryos were harvested in cold PBS, fixed in either $4 \%$ paraformaldehyde for various times ranging from $1 \mathrm{~h}$ to overnight (hematoxylin-eosin staining, immunohistochemistry) or $0.2 \%$ glutaraldehyde in $0.1 \mathrm{M}$ phosphate buffer $\mathrm{pH} 7.3,2 \mathrm{mM} \mathrm{MgCl}_{2}$ and $5 \mathrm{mM} \mathrm{EGTA}$ for $1 \mathrm{~h}$ (for $\mathrm{X}$-gal staining). Fixed embryos were cryoprotected in $30 \%$ sucrose overnight at $4^{\circ} \mathrm{C}$, embedded and frozen in OCT (Tissue Freezing Medium, Jung). Horizontal frozen sections were done at 6-8 $\mu \mathrm{m}$ thickness. The cryosections were washed three times in PBS and subsequently stained with an antibody or hybridized with RNA antisense probes.

\section{$X$-gal staining}

The $\beta$-galactosidase assay was carried out as described by (Hogan et al., 1986). After the fixation, the cryosections were directly stained with the staining solution (rinse buffer supplemented with $5 \mathrm{mM}$ potassium ferricyanide, $5 \mathrm{mM}$ potassium ferrocyanide, $20 \mathrm{mM}$ Tris $\mathrm{pH} 7.3$, and $1 \mathrm{mg} /$ $\mathrm{ml} \mathrm{X-gal).} \mathrm{For} \mathrm{whole-mount} \mathrm{stainings,} \mathrm{fixed} \mathrm{embryos} \mathrm{were} \mathrm{washed} \mathrm{three}$ times in rinse buffer $\left(0.1 \mathrm{M}\right.$ phosphate buffer $\mathrm{pH} 7.3,2 \mathrm{mM} \mathrm{MgCl}_{2}, 20 \mathrm{mM}$ Tris $\mathrm{pH} 7.3,0.01 \%$ sodium deoxycholate and $0.02 \%$ Nonidet $\mathrm{P}-40$ ), and incubated overnight at $37^{\circ} \mathrm{C}$ in staining solution.

\section{Immunohistochemistry}

The cryosections were re-fixed for $10 \mathrm{~min}$. in $4 \%$ paraformaldehyde, washed with PBS, permeabilized with PBS/0.1\%Tween20 (PBT) for 15 min. prior to blocking. Sections were blocked for $30 \mathrm{~min}$. in 10\%BSA/PBT, incubated overnight with primary antibodies at room temperature or $4^{\circ} \mathrm{C}$, washed three times with PBS, incubated 40 minutes at room temperature with secondary antibodies, washed three times with PBS, exposed 5 minutes to DAPI/PBS and mounted in glycerol. Primary antibodies and sera used were: anti- $\alpha$-crystallin (a gift of Sam Ziegler, NEI), anti- $\beta$ crystallin (a gift of Sam Ziegler, NEI), anti- $\gamma$-crystallin (a gift of Hisato Kondoh), anti- $\beta$ A3-crystallin (a gift of Hisato Kondoh), anti-MIP26 (a gift of Joe Horwitz), anti- $\beta$-tubulin (TUJ-1, R\&D Systems), anti-Chx10 (Vsx2) (Exalpha Biologicals), anti-Pax6 (Covance), anti-Pax6 (DSHB), antiProx1 (Chemicon), anti-PD808 (Kozmik et al., 2003), anti-Pax2 (Zymed), anti-Six3 (a gift of Paola Bovolenta), anti-Meis1 (a gift of Arthur Buchberg), anti-Meis2 (a gift of Arthur Buchberg), anti-Flag (OctA, Santa Cruz), antisyntaxin (Sigma), anti-PKC $\alpha$ (Sigma), anti-Brn3b (Santa Cruz), anti-OLF1 (a gift of Randall Reed), anti-calretinin (Sigma), anti-GAD65/67 (Sigma), anti-Glyt1 (Chemicon), anti-cMaf (Santa Cruz), anti-CRX (a gift of Cheryl Craft) (Zhu and Craft, 2000), anti-NR2e3 (p183, a gift of Shiming Chen), anti-M-opsin (a gift of Cheryl Craft) (Zhu et al., 2003), anti-S-opsin (a gift of Cheryl Craft) (Zhu et al., 2003), anti-arrestin (a gift of Dale Gregerson), anti-rhodopsin (Sigma), anti-GRK1 (Sigma). The following secondary antibodies were used: Alexa-488- or 594-conjugated goat anti-mouse or anti-rabbit IgG, Alexa-594-conjugated donkey anti-goat IgG (Molecular Probes).

\section{Whole-mount In situ hybridization}

Plasmid was linearized with appropriate restriction enzyme and antisense riboprobe was synthesized using the DIG RNA labeling kit (Roche).

Fixed embryos were washed three times in PBS/0.1\%Tween20 (PBT) and thereafter bleached with methanol: $30 \% \mathrm{H}_{2} \mathrm{O}_{2}(4: 1)$ for $20 \mathrm{~min}$ at $\mathrm{RT}$. After three times washing in PBT, Proteinase $\mathrm{K}(0.05 \mathrm{U} / \mathrm{ml}$ PBT) was applied for $15 \mathrm{~min}$ at RT. The reaction was stopped with two washes (5 min each) of glycin solution ( $2 \mathrm{mg} / \mathrm{ml}$ PBT). Glycin was washed out with PBT and embryos were refixed with $0.2 \%$ glutaraldehyde $/ 4 \%$ paraformaldehyde for $20 \mathrm{~min}$ at RT. The embryos were then rinsed two times in PBT and were prehybridized for $90 \mathrm{~min}$ at $70^{\circ} \mathrm{C}$ in prehybridization solution
( $50 \%$ formamide, $5 \times$ SSC pH 4.5, 5 mM EDTA, 0.1\%Tweeen20 with 0,05 $\mathrm{mg} / \mathrm{ml}$ Heparin). After that half of the prehybridization solution was replaced with prewarmed hybridization solution ( $50 \%$ formamide, $5 \times$ SSC $\mathrm{pH} 4.5,5 \mathrm{mM}$ EDTA, 0.1\%Tweeen20, $50 \mu \mathrm{g} / \mathrm{ml}$ Heparin, $50 \mu \mathrm{g} / \mathrm{ml}$ tRNA and $50 \mu \mathrm{g} / \mathrm{ml}$ herring sperm DNA). Meanwhile digoxigenin-labeled riboprobe in $100 \mu$ l hybridization solution was denaturated for $10 \mathrm{~min}$ at $75-80^{\circ} \mathrm{C}$. The denatured probe was added to the samples (final concentration $0.5-1 \mu \mathrm{g} / \mathrm{ml})$ and incubated overnight at $70^{\circ} \mathrm{C}$. After the hybridization unbound riboprobe was washed two times (30min each) in prewarmed $\left(70^{\circ} \mathrm{C}\right)$ solution I $(50 \%$ formamide, $4 \times$ SSC, $1 \%$ SDS $)$. Then the samples were equilibrated in solution $\mathrm{I} / \mathrm{II}(1: 1)$ for $10 \mathrm{~min}$ at $70^{\circ} \mathrm{C}$. Afterwards samples were washed three times $\left(5 \mathrm{~min}\right.$ each) at $70^{\circ} \mathrm{C}$ in solution II (0.5 $\mathrm{M} \mathrm{NaCl}, 10 \mathrm{mM}$ Tris-Cl pH 7.5, 0.1\% Tween20) and were treated with RNasel in the solution II twice per 30min at RT. After that embryos were washed twice $\left(30 \mathrm{~min}\right.$ each) in prewarmed $\left(70^{\circ} \mathrm{C}\right)$ solution III $(50 \%$ formamide, 2xSSC). Following steps were three washes in TBST (130 $\mathrm{mM} \mathrm{NaCl}, 2.7 \mathrm{mM} \mathrm{KCl}, 25 \mathrm{mM}$ Tris- $\mathrm{Cl} \mathrm{pH} \mathrm{7.5,} \mathrm{0.1 \%} \mathrm{Tween20)} \mathrm{with} 2 \mathrm{mM}$ Levamisole. Blocking was performed in $10 \%$ heat inactivated sheep serum in TBST for 2 hours at RT. After that embryos were incubated overnight with anti-digoxigenin-AP Fab fragments (Roche, 1:1000) in $10 \%$ heat inactivated sheep serum in TBST at RT. Unbound antidigoxigenin Fab fragments were removed by extensive washing in TBST with $2 \mathrm{mM}$ Levamisole. After that embryos were rinsed twice for $20 \mathrm{~min}$ in alkaline phosphatase staining buffer $(100 \mathrm{mM} \mathrm{NaCl}, 100 \mathrm{mM}$ Tris- $\mathrm{Cl} \mathrm{pH}$ 9.5, $50 \mathrm{mM} \mathrm{MgCl}, 0.1 \%$ Tween20). Staining was performed with $20 \mu \mathrm{l}$ NBT/BCIP Stock Solution (Roche) in $10 \mathrm{ml}$ staining buffer at dark and RT. Reaction was stopped with several washes $1 \mathrm{mM}$ EDTA in PBT. Plasmid carrying following cDNAs were used: mouse Pax6 (provided by Peter Gruss), mouse FoxE3 (provided by Peter Carlsson) (Blixt et al., 2000), mouse Mab21l1 (provided by Giacomo Consalez), and Tripedalia cystophora PaxB (Kozmik et al., 2003).

\section{Electroforetic mobility shift assay (EMSA)}

EMSA with the full-length FLAG-tagged PaxB and Pax6 was performed as previously described (Kozmik et al., 2003) using doublestranded oligonucleotides comprising autoregulatory Pax6 binding site from lens EE or retina-specific $\alpha$-enhancer binding sites Ret and Ret2 (Schwarz et al., 2000).

\section{Acknowledgements}

We would like to thank Mrs. Veronika Noskova for excellent technical assistance. We thank Ales Cvekl and Romana Kucerova for critical reading of the manuscript and helpful discussions. We wish to thank Cheryl Craft from Mary D. Allen Laboratory for Vison Research, Doheny Eye Institute for CRX, S- and M-opsin antibodies. We are grateful to J. Samuel Zigler Jr. and Hisato Kondoh for anti-crystallin antibodies, Joe Horwitz for MIP26 antibody, Paola Bovolenta for Six3 antibody, Arthur Buchberg for Meis1 and Meis2 antibodies, Randall Reed for OLF-1 antibody, Shiming Chen for NR2e3 antibody, Dale Gregerson for arrestin antibody, Peter Carlsson for FoxE3, Giacomo Consalez for Mab2111 and Peter Gruss for Pax6 riboprobe plasmid. The Pax6 monoclonal antibody developed by A. Kawakami was obtained from the Developmental Studies Hybridoma Bank developed under the auspices of the NICHD and maintained by The University of lowa, Department of Biological Sciences, lowa City, IA 52242. This work was supported in part by grants no. AV0Z50520514 and IAA500520908 from the Academy of Sciences of the Czech Republic, by Center for Applied Genomics grant no. 1 M6837805002 awarded by Ministry of Education, Youths and Sports of the Czech Republic and grant no. 204/08/1618 from the Grant Agency of Czech Republic.

\section{References}

AOTA, S., NAKAJIMA, N., SAKAMOTO, R., WATANABE, S., IBARAKI, N. and OKAZAKI, K. (2003). Pax6 autoregulation mediated by direct interaction of 
Pax6 protein with the head surface ectoderm-specific enhancer of the mouse Pax6 gene. Dev Biol 257: 1-13.

ASHERY-PADAN, R., MARQUARDT, T., ZHOU, X. and GRUSS, P. (2000). Pax6 activity in the lens primordium is required for lens formation and for correct placement of a single retina in the eye. Genes Dev 14: 2701-2711.

BAUMER, N., MARQUARDT, T., STOYKOVA, A., SPIELER, D., TREICHEL, D., ASHERY-PADAN, R. and GRUSS, P. (2003). Retinal pigmented epithelium determination requires the redundant activities of Pax2 and Pax6. Development 130: 2903-2915.

BLIXT, A., LANDGREN, H., JOHANSSON, B.R. and CARLSSON, P. (2007). Foxe3 is required for morphogenesis and differentiation of the anterior segment of the eye and is sensitive to Pax6 gene dosage. Dev Biol 302: 218-229.

BLIXT, A., MAHLAPUU, M., AITOLA, M., PELTO-HUIKKO, M., ENERBACK, S. and CARLSSON, P. (2000). A forkhead gene, FoxE3, is essential for lens epithelial proliferation and closure of the lens vesicle. Genes Dev 14: 245-254.

BOUCHARD, M., PFEFFER, P. and BUSSLINGER, M. (2000). Functional equivalence of the transcription factors Pax 2 and $P a x 5$ in mouse development. Development 127: 3703-3713.

BROWN, N.L., PATEL, S., BRZEZINSKI, J. and GLASER, T. (2001). Math5 is required for retinal ganglion cell and optic nerve formation. Development 128: 2497-2508.

BUMSTED-O'BRIEN, K.M., HENDRICKSON, A., HAVERKAMP, S., ASHERYPADAN, R. and SCHULTE, D. (2007). Expression of the homeodomain transcription factor Meis2 in the embryonic and postnatal retina. J Comp Neuro/505: 58-72.

BURMEISTER, M., NOVAK, J., LIANG, M.Y., BASU, S., PLODER, L., HAWES, N.L., VIDGEN, D., HOOVER, F., GOLDMAN, D., KALNINS, V.I. et al. (1996). Ocular retardation mouse caused by $\mathrm{Chx10}$ homeobox null allele: impaired retinal progenitor proliferation and bipolar cell differentiation. Nat Genet 12: 376-384.

COLLINSON, J.M., HILL, R.E. and WEST, J.D. (2000). Different roles for Pax6 in the optic vesicle and facial epithelium mediate early morphogenesis of the murine eye. Development 127: 945-956.

CVEKL, A. and PIATIGORSKY, J. (1996). Lens development and crystallin gene expression: many roles for Pax-6. Bioessays 18: 621-630.

CZERNY, T. and BUSSLINGER, M. (1995). DNA-binding and transactivation properties of Pax-6: three amino acids in the paired domain are responsible for the different sequence recognition of Pax-6 and BSAP (Pax-5). Mol Cell Biol 15: 2858-2871.

CZERNY, T., HALDER, G., KLOTER, U., SOUABNI, A., GEHRING, W.J. and BUSSLINGER, M. (1999). twin of eyeless, a second Pax-6 gene of Drosophila, acts upstream of eyeless in the control of eye development. Mol Cell3: 297-307.

DAVIS-SILBERMAN, N., KALICH, T., ORON-KARNI, V., MARQUARDT, T., KROEBER, M., TAMM, E.R. and ASHERY-PADAN, R. (2005). Genetic dissection of Pax 6 dosage requirements in the developing mouse eye. Hum Mol Genet 14: $2265-2276$.

DAVIS, J.A. and REED, R.R. (1996). Role of Olf-1 and Pax-6 transcription factors in neurodevelopment. $J$ Neurosci 16: 5082-5094.

DIMANLIG, P.V., FABER, S.C., AUERBACH, W., MAKARENKOVA, H.P. and LANG, R.A. (2001). The upstream ectoderm enhancer in Pax6 has an important role in lens induction. Development 128: 4415-4424

DORFLER, P. and BUSSLINGER, M. (1996). C-terminal activating and inhibitory domains determine the transactivation potential of BSAP (Pax-5), Pax-2 and Pax-8. EMBO J 15: 1971-1982.

DUNCAN, M.K., XIE, L., DAVID, L.L., ROBINSON, M.L., TAUBE, J.R., CUI, W. and RENEKER, L.W. (2004). Ectopic Pax6 expression disturbs lens fiber cell differentiation. Invest Ophthalmol Vis Sci 45: 3589-3598.

DUPARC, R.H., ABDOUH, M., DAVID, J., LEPINE, M., TETREAULT, N. and BERNIER, G. (2007). Pax6 controls the proliferation rate of neuroepithelial progenitors from the mouse optic vesicle. Dev Biol 301: 374-387.

DYER, M.A., LIVESEY, F.J., CEPKO, C.L. and OLIVER, G. (2003). Prox1 function controls progenitor cell proliferation and horizontal cell genesis in the mammalian retina. Nat Genet 34: 53-58.

EBERHARD, D., JIMENEZ, G., HEAVEY, B. and BUSSLINGER, M. (2000). Transcriptional repression by Pax5 (BSAP) through interaction with corepres- sors of the Groucho family. EMBO J 19: 2292-2303.

EPSTEIN, J.A., GLASER, T., CAI, J., JEPEAL, L., WALTON, D.S. and MAAS, R.L. (1994). Two independent and interactive DNA-binding subdomains of the Pax6 paired domain are regulated by alternative splicing. Genes Dev 8: 2022-2034.

FAVOR, J., SANDULACHE, R., NEUHAUSER-KLAUS, A., PRETSCH, W., CHATTERJEE, B., SENFT, E., WURST, W., BLANQUET, V., GRIMES, P., SPORLE, R. et al. (1996). The mouse Pax2(1Neu) mutation is identical to a human PAX2 mutation in a family with renal-coloboma syndrome and results in developmental defects of the brain, ear, eye, and kidney. Proc Natl Acad Sci USA 93: 13870-13875.

FU, W. and NOLL, M. (1997). The Pax2 homolog sparkling is required for development of cone and pigment cells in the Drosophila eye. Genes Dev 11: 20662078.

GEHRING, W.J. (2002). The genetic control of eye development and its implications for the evolution of the various eye-types. Int J Dev Biol 46: 65-73.

GEHRING, W.J. (2005). New perspectives on eye development and the evolution of eyes and photoreceptors. J Hered 96: 171-184.

GEHRING, W.J. and IKEO, K. (1999). Pax 6: mastering eye morphogenesis and eye evolution. Trends Genet 15: 371-377.

GLASER, T., WALTON, D.S. and MAAS, R.L. (1992). Genomic structure, evolutionary conservation and aniridia mutations in the human PAX6 gene. Nat Genet 2: 232-239.

GRINDLEY, J.C., DAVIDSON, D.R. and HILL, R.E. (1995). The role of Pax-6 in eye and nasal development. Development 121: 1433-1442.

HALDER, G., CALLAERTS, P. and GEHRING, W.J. (1995). Induction of ectopic eyes by targeted expression of the eyeless gene in Drosophila. Science 267: 1788-1792.

HANKS, M., WURST, W., ANSON-CARTWRIGHT, L., AUERBACH, A.B. and JOYNER, A.L. (1995). Rescue of the En-1 mutant phenotype by replacement of En-1 with En-2. Science 269: 679-682.

HANKS, M.C., LOOMIS, C.A., HARRIS, E., TONG, C.X., ANSON-CARTWRIGHT, L., AUERBACH, A. and JOYNER, A. (1998). Drosophila engrailed can substitute for mouse Engrailed1 function in mid-hindbrain, but not limb development. Development 125: 4521-4530.

HANSON, I. and VAN HEYNINGEN, V. (1995). Pax6: more than meets the eye. Trends Genet 11: 268-272.

HANSON, I.M., FLETCHER, J.M., JORDAN, T., BROWN, A., TAYLOR, D., ADAMS, R.J., PUNNETT, H.H. and VAN HEYNINGEN, V. (1994). Mutations at the PAX6 locus are found in heterogeneous anterior segment malformations including Peters' anomaly. Nat Genet 6: 168-173.

HAVERKAMP, S. and WASSLE, H. (2000). Immunocytochemical analysis of the mouse retina. J Comp Neurol 424: 1-23.

HILL, R.E., FAVOR, J., HOGAN, B.L., TON, C.C., SAUNDERS, G.F., HANSON, I.M., PROSSER, J., JORDAN, T., HASTIE, N.D. and VAN HEYNINGEN, V. (1991). Mouse small eye results from mutations in a paired-like homeoboxcontaining gene. Nature 354: 522-525.

HOGAN, B.L., HORSBURGH, G., COHEN, J., HETHERINGTON, C.M., FISHER, G. and LYON, M.F. (1986). Small eyes (Sey): a homozygous lethal mutation on chromosome 2 which affects the differentiation of both lens and nasal placodes in the mouse. J Embryol Exp Morphol 97: 95-110.

HUFNAGEL, R.B., RIESENBERG, A.N., SAUL, S.M. and BROWN, N.L. (2007). Conserved regulation of Math5 and Math1 revealed by Math5-GFP transgenes. Mol Cell Neurosci 36: 435-448.

HUTCHESON, D.A., HANSON, M.I., MOORE, K.B., LE, T.T., BROWN, N.L. and VETTER, M.L. (2005). bHLH-dependent and -independent modes of Ath5 gene regulation during retinal development. Development 132: 829-839.

INOUE, T., HOJO, M., BESSHO, Y., TANO, Y., LEE, J.E. and KAGEYAMA, R. (2002). Math3 and NeuroD regulate amacrine cell fate specification in the retina. Development 129: 831-842.

KAMMANDEL, B., CHOWDHURY, K., STOYKOVA, A., APARICIO, S., BRENNER, S. and GRUSS, P. (1999). Distinct cis-essential modules direct the time-space pattern of the Pax6 gene activity. Dev Biol 205: 79-97.

KIM, J. and LAUDERDALE, J.D. (2006). Analysis of Pax6 expression using a BAC transgene reveals the presence of a paired-less isoform of Pax6 in the eye and olfactory bulb. Dev Biol 292: 486-505. 
KIM, J. and LAUDERDALE, J.D. (2008). Overexpression of pairedless Pax6 in the retina disrupts corneal development and affects lens cell survival. Dev Bio/313: 434-454.

KLEINJAN, D.A., SEAWRIGHT, A., CHILDS, A.J. and VAN HEYNINGEN, V. (2004). Conserved elements in Pax6 intron 7 involved in (auto)regulation and alternative transcription. Dev Biol 265: 462-477.

KOZMIK, Z. (2005). Pax genes in eye development and evolution. Curr Opin Genet Dev 15: 430-438.

KOZMIK, Z., DAUBE, M., FREI, E., NORMAN, B., KOS, L., DISHAW, L.J., NOLL, M. and PIATIGORSKY, J. (2003). Role of Pax genes in eye evolution: a cnidarian PaxB gene uniting Pax2 and Pax6 functions. Dev Cell 5: 773-785.

KOZMIK, Z., RUZICKOVA, J., JONASOVA, K., MATSUMOTO, Y., VOPALENSKY, P., KOZMIKOVA, I., STRNAD, H., KAWAMURA, S., PIATIGORSKY, J., PACES, V. et al. (2008). Assembly of the cnidarian camera-type eye from vertebrate-like components. Proc Natl Acad Sci USA 105: 8989-8993.

KRESLOVA, J., MACHON, O., RUZICKOVA, J., LACHOVA, J., WAWROUSEK, E.F., KEMLER, R., KRAUSS, S., PIATIGORSKY, J. and KOZMIK, Z. (2007). Abnormal lens morphogenesis and ectopic lens formation in the absence of beta-catenin function. Genesis 45: 157-168.

LAKOWSKI, J., MAJUMDER, A. and LAUDERDALE, J.D. (2007). Mechanisms controlling Pax6 isoform expression in the retina have been conserved between teleosts and mammals. Dev Biol 307: 498-520.

LECHNER, M.S. and DRESSLER, G.R. (1996). Mapping of Pax-2 transcription activation domains. J Biol Chem 271: 21088-21093.

LIU, W., LAGUTIN, O.V., MENDE, M., STREIT, A. and OLIVER, G. (2006). Six3 activation of Pax6 expression is essential for mammalian lens induction and specification. EMBO J 25: 5383-5395.

LIU, W., WANG, J.H. and XIANG, M. (2000). Specific expression of the LIM/ homeodomain protein Lim-1 in horizontal cells during retinogenesis. Dev Dyn 217: 320-325.

LIVESEY, F.J. and CEPKO, C.L. (2001). Vertebrate neural cell-fate determination: lessons from the retina. Nat Rev Neurosci 2: 109-118.

MACNEIL, M.A. and MASLAND, R.H. (1998). Extreme diversity among amacrine cells: implications for function. Neuron 20: 971-982.

MANUEL, M., PRATT, T., LIU, M., JEFFERY, G. and PRICE, D.J. (2008). Overexpression of Pax6 results in microphthalmia, retinal dysplasia and defective retinal ganglion cell axon guidance. BMC Dev Biol 8: 59.

MARQUARDT, T., ASHERY-PADAN, R., ANDREJEWSKI, N., SCARDIGLI, R., GUILLEMOT, F. and GRUSS, P. (2001). Pax6 is required for the multipotent state of retinal progenitor cells. Cell 105: 43-55.

MEDINA-MARTINEZ, O., BROWNELL, I., AMAYA-MANZANARES, F., HU, Q., BEHRINGER, R.R. and JAMRICH, M. (2005). Severe defects in proliferation and differentiation of lens cells in Foxe3 null mice. Mol Cell Biol 25: 8854-8863.

MU, X., FU, X., SUN, H., BEREMAND, P.D., THOMAS, T.L. and KLEIN, W.H. (2005). A gene network downstream of transcription factor Math5 regulates retinal progenitor cell competence and ganglion cell fate. Dev Biol280: 467-481.

MUI, S.H., KIM, J.W., LEMKE, G. and BERTUZZI, S. (2005). Vax genes ventralize the embryonic eye. Genes Dev 19: 1249-1259.

NORNES, H.O., DRESSLER, G.R., KNAPIK, E.W., DEUTSCH, U. and GRUSS, P. (1990). Spatially and temporally restricted expression of Pax2 during murine neurogenesis. Development 109: 797-809.

OLIVER, G., MAILHOS, A., WEHR, R., COPELAND, N.G., JENKINS, N.A. and GRUSS, P. (1995). Six3, a murine homologue of the sine oculis gene, demarcates the most anterior border of the developing neural plate and is expressed during eye development. Development 121: 4045-4055.

PAN, L., YANG, Z., FENG, L. and GAN, L. (2005). Functional equivalence of Brn3 POU-domain transcription factors in mouse retinal neurogenesis. Development 132: 703-712.

PAPATSENKO, D., NAZINA, A. and DESPLAN, C. (2001). A conserved regulatory element present in all Drosophilarhodopsin genes mediates Pax6 functions and participates in the fine-tuning of cell-specific expression. Mech Dev 101: 143153.

PHILIPS, G.T., STAIR, C.N., YOUNG LEE, H., WROBLEWSKI, E., BERBEROGLU,
M.A., BROWN, N.L. and MASTICK, G.S. (2005). Precocious retinal neurons: Pax6 controls timing of differentiation and determination of cell type. Dev Biol 279: 308-321.

QUIRING, R., WALLDORF, U., KLOTER, U. and GEHRING, W.J. (1994). Homology of the eyeless gene of Drosophila to the Small eye gene in mice and Aniridia in humans. Science 265: 785-789.

SHENG, G., THOUVENOT, E., SCHMUCKER, D., WILSON, D.S. and DESPLAN, C. (1997). Direct regulation of rhodopsin 1 by Pax-6/eyeless in Drosophila: evidence for a conserved function in photoreceptors. Genes Dev 11: 11221131.

SCHEDL, A., ROSS, A., LEE, M., ENGELKAMP, D., RASHBASS, P., VAN HEYNINGEN, V. and HASTIE, N.D. (1996). Influence of PAX6 gene dosage on development: overexpression causes severe eye abnormalities. Cell86: 71-82.

SCHWARZ, M., CECCONI, F., BERNIER, G., ANDREJEWSKI, N., KAMMANDEL, B., WAGNER, M. and GRUSS, P. (2000). Spatial specification of mammalian eye territories by reciprocal transcriptional repression of $\mathrm{Pax} 2$ and Pax6. Development 127: 4325-4334.

SORIANO, P. (1999). Generalized lacZ expression with the ROSA26 Cre reporter strain. Nat Genet 21: 70-71.

TANG, H.K., SINGH, S. and SAUNDERS, G.F. (1998). Dissection of the transactivation function of the transcription factor encoded by the eye developmental gene PAX6. J Biol Chem 273: 7210-7221.

TON, C.C., HIRVONEN, H., MIWA, H., WEIL, M.M., MONAGHAN, P., JORDAN, T., VAN HEYNINGEN, V., HASTIE, N.D., MEIJERS-HEIJBOER, H., DRECHSLER, M. et al. (1991). Positional cloning and characterization of a paired box- and homeobox-containing gene from the aniridia region. Cell 67: 1059-1074.

TORRES, M., GOMEZ-PARDO, E. and GRUSS, P. (1996). Pax2 contributes to inner ear patterning and optic nerve trajectory. Development 122: 3381-3391.

VAN RAAMSDONK, C.D. and TILGHMAN, S.M. (2000). Dosage requirement and allelic expression of PAX6 during lens placode formation. Development 127: 5439-5448.

WANG, S.W., KIM, B.S., DING, K., WANG, H., SUN, D., JOHNSON, R.L., KLEIN, W.H. and GAN, L. (2001). Requirement for math5 in the development of retinal ganglion cells. Genes Dev 15: 24-29.

WIGLE, J.T., CHOWDHURY, K., GRUSS, P. and OLIVER, G. (1999). Prox1 function is crucial for mouse lens-fibre elongation. Nat Genet 21: 318-322.

WILLIAMS, S.C., ALTMANN, C.R., CHOW, R.L., HEMMATI-BRIVANLOU, A. and LANG, R.A. (1998). A highly conserved lens transcriptional control element from the Pax-6 gene. Mech Dev 73: 225-229.

XIANG, M., ZHOU, L., MACKE, J.P., YOSHIOKA, T., HENDRY, S.H., EDDY, R.L., SHOWS, T.B. and NATHANS, J. (1995). The Brn-3 family of POU-domain factors: primary structure, binding specificity, and expression in subsets of retinal ganglion cells and somatosensory neurons. J Neurosci 15: 4762-4785.

XU, P.X., ZHANG, X., HEANEY, S., YOON, A., MICHELSON, A.M. and MAAS, R.L. (1999). Regulation of Pax6 expression is conserved between mice and flies. Development 126: 383-395.

XU, S., SUNDERLAND, M.E., COLES, B.L., KAM, A., HOLOWACZ, T., ASHERYPADAN, R., MARQUARDT, T., MCINNES, R.R. and VAN DER KOOY, D. (2007). The proliferation and expansion of retinal stem cells require functional Pax6. Dev Biol 304: 713-721.

YAMADA, R., MIZUTANI-KOSEKI, Y., HASEGAWA, T., OSUMI, N., KOSEKI, H. and TAKAHASHI, N. (2003). Cell-autonomous involvement of Mab21l1 is essential for lens placode development. Development 130: 1759-1770.

ZHANG, X., FRIEDMAN, A., HEANEY, S., PURCELL, P. and MAAS, R.L. (2002). Meis homeoproteins directly regulate $P a x 6$ during vertebrate lens morphogenesis. Genes Dev 16: 2097-2107.

ZHU, X., BROWN, B., LI, A., MEARS, A.J., SWAROOP, A. and CRAFT, C.M. (2003). GRK1-dependent phosphorylation of $S$ and $M$ opsins and their binding to cone arrestin during cone phototransduction in the mouse retina. $J$ Neurosci 23: 6152-6160.

ZHU, X. and CRAFT, C.M. (2000). Modulation of CRX transactivation activity by phosducin isoforms. Mol Cell Biol 20: 5216-5226. 


\section{Further Related Reading, published previously in the Int. J. Dev. Biol.}

See our recent Special Issue Fertilization, in honor of David L. Garbers and edited by Paul M. Wassarman and Victor D. Vacquier at: http://www.ijdb.ehu.es/web/contents.php?vol=52\&issue=5-6

Molecular evolution of the vertebrate mechanosensory cell and ear Bernd Fritzsch, Kirk W. Beisel, Sarah Pauley and Garrett Soukup Int. J. Dev. Biol. (2007) 51: 663-678

Cubozoan jellyfish: an Evo/Devo model for eyes and other sensory systems Joram Piatigorsky and Zbynek Kozmik Int. J. Dev. Biol. (2004) 48: 719-729

Regulation of gene expression by Pax6 in ocular cells: a case of tissue-preferred expression of crystallins in lens

Ales Cvekl, Ying Yang, Bharesh K. Chauhan and Kveta Cveklova

Int. J. Dev. Biol. (2004) 48: 829-844

Interplay of Pax6 and SOX2 in lens development as a paradigm of genetic switch mechanisms for cell differentiation

Hisato Kondoh, Masanori Uchikawa and Yusuke Kamachi

Int. J. Dev. Biol. (2004) 48: 819-827

The eyeless mutant gene (e) in the Mexican axolotl (Ambystoma mexicanum) affects pax-6 expression and forebrain axonogenesis

G W Eagleson, L M Gerlach and T A Platz

Int. J. Dev. Biol. (2001) 45: 653-660

The eyeless mutant gene (e) in the Mexican axolotl (Ambystoma mexicanum) affects pax-6 expression and forebrain axonogenesis

G W Eagleson, L M Gerlach and T A Platz

Int. J. Dev. Biol. (2001) 45: 653-660

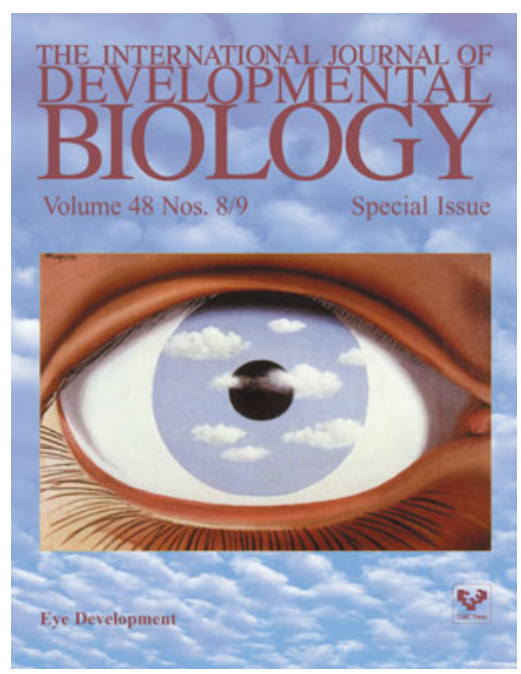

2006 ISI **Impact Factor $=3.577^{* *}$

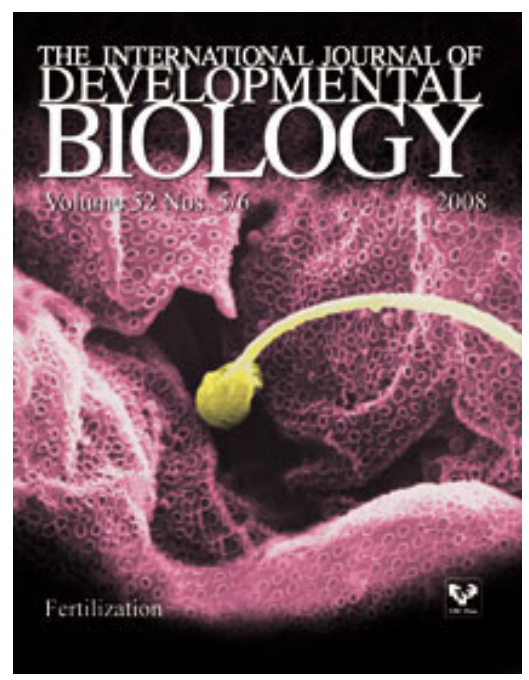

